\title{
CEO Turnover Announcements and Information Frictions
}

\author{
August 2019
}

\begin{abstract}
This paper analyzes the market reaction to CEO turnover announcements in the presence of information frictions. We find that the market reaction to forced CEO turnover announcements is negatively related to the level of asymmetric information between a firm and its investors. No such relation exists for voluntary turnovers. We also find that in cases where information frictions are high, companies attempt to present forced turnover as voluntary and this behavior leads to a less negative market response. Overall, our results suggest that firms act strategically when disclosing information about CEO turnover to avoid a negative market reaction.
\end{abstract}

Keywords: CEO turnover, information asymmetry, corporate governance, information disclosure, market reaction.

JEL Classification: G14; G30; G34. 


\section{Introduction}

On February 27, 2006, the Phillips-Van Heusen Corporation (PVH) announced a CEO turnover without providing a reason. The stock price dropped by 2 percent on the announcement date and continued to drop for several days after the turnover announcement. In contrast, Symantec announced firing its CEO on July 25, 2012, but its stock price rose by 13.5 percent that day and continued to increase after the announcement. What drives the difference? Why do some companies enjoy a positive market reaction to their CEO turnover announcement, while other companies receive a negative market reaction? How does the stock market react to CEO turnover events, and what factors affect this market reaction? Despite the substantial literatures on CEO turnover and market reaction, little work has been done to study these questions. This paper aims to fill the gap. We study how market reaction to CEO turnovers depends on information asymmetry and try to explain away some of the conflicting evidence found in the prior literature regarding this issue.

The existing literature provides mixed evidence on the market consequences of CEO turnover events. While some papers find no market reaction to CEO turnover events (see Warner, Watts, and Wruck (1988) among others), other works suggest otherwise. Huson, Malatesta, and Parrino (2004) and Adams and Mansi (2009) find a significant positive abnormal return following CEO turnover announcements. The findings in these two papers are supported by the improved-management hypothesis. If turnover signifies current management being replaced by one of higher ability, we can therefore expect the market to react positively. By contrast, Khanna and Poulsen (1995), Dedman and Lin (2002) and Ertugrul and Krishnan (2011) find that the market reacts negatively to CEO turnover announcements. Their explanation is consistent with the over-assessed-ability hypothesis. If a CEO is fired, it is likely that their ability was previously over-assessed, and so we can expect the market to react negatively to reflect such a reassessment of ability. Overall, there does not yet exist a consensus in the literature regarding stock market reaction to CEO turnover announcement. We find that information asymmetry might play an important role in explaining the difference in market reactions. The level of information asymmetry directly affect the nature of information revealed from CEO turnover announcement, generating different market reactions.

Specifically, we examine market reaction to CEO turnover announcements under different levels of asymmetric information between a firm and its investors. Our paper makes two contributions to the existing literature. First, we look at the stock market reaction to a hand-collected sample of 750 CEO turnover announcements between 2004 and 2014. Analyzing the market reaction to these turnover events, we find that the market reaction depends both on the type of CEO turnover and the level of asymmetric information. The type of turnover matters because of the information content in the turnover announcement. We look at the effect of turnover types (forced vs. voluntary) and information frictions after controlling for the source of the replacement hire (internal vs. external). In particular, when turnover is forced, the market reaction is negatively related to the level of asymmetric information between a company and its investors: if the level of asymmetric information is high, the market reacts negatively to a forced turnover announcement, and vice versa. When 
turnover is voluntary, however, the market reaction is negligible and is unrelated to the level of asymmetric information. The information content of voluntary turnover announcements is lower than that of forced turnovers. Therefore, the degree of attention to such announcements should matter less, simply because there is significantly less information disclosed. Consistent with these expectations, we find that the level of asymmetric information predicts substantial variation in market returns to CEO turnover announcement when significantly new information is made available (forced turnovers), but not when the announcement contains little new information (voluntary turnovers).

The second contribution of the paper is related to the strategic behavior of firms when announcing CEO turnovers. Presumably, in the presence of high information frictions, firms have an incentive to present forced turnovers as voluntary. We find evidence consistent with this conjecture. The proportion of companies that attempt to embellish information related to forced turnovers increases with the level of asymmetric information. Further, such embellishing behavior helps to alleviate negative market reaction during the announcement period, especially for companies with a high level of asymmetric information.

Our results are robust to different proxies for asymmetric information. Specifically, we use the following proxies to measure the level of asymmetric information: (i) analyst coverage, which measures the number of analysts following a company during the announcement period; (ii) firm size, which is measured by a firm's market capitalization; (iii) analyst forecasting error based on mean/median, which is the difference between the mean/median of analyst forecasts for a firm's next-year EPS (earning per share) and true EPS; (iv) analyst forecasting dispersion, which is measured by the standard deviation of analyst forecasts; (v) S\&P Index code, which is a dummy variable that indicates whether a firm belongs to the S\&P500; and (vi) distance, which is the distance between a firm's headquarters and the nearest major cities. We measure market reaction by the cumulative abnormal return (CAR) of a firm' s stock around the turnover announcement. Our results are also robust to different return models for calculating abnormal return.

Overall, our findings suggest that it is important to consider the level of information asymmetry when analyzing market reaction, in addition to the type of CEO turnover announcement. Firms may act strategically when they have to announce a forced turnover by attempting to convince investors that the turnover is voluntary to avoid a potential drop in stock price.

The remainder of this paper is organized as follows. Section 2 describes the related literature and develops our main hypothesis. Section 3 describes the data and variables used in our empirical estimations and presents the empirical method used in this paper. Section 4 describes our empirical results. Section 5 checks the robustness of our results. Section 6 concludes. 


\section{Related Literature and Main Hypothesis}

\subsection{CEO turnover literature}

Many papers in the literature agree that CEOs are replaced when firms perform poorly. Kaplan and Minton (2012) confirm this result using recent data. They find that internal turnover is significantly related to three components of firm stock performance: firm performance relative to the industry, industry performance relative to the overall market, and performance of the overall stock market.

The relationship between these components has increased since 2000. Dikolli, Mayew, and Nanda (2014) present a similar result. They find that firm performance reveals information about a CEO's ability level and find that CEO survival is associated with superior firm performance. However, the empirical literature on CEO turnover fails to give a clear conclusion about stock market reactions. Warner, Watts, and Wruck (1988) study the relationship between a firm's stock return and top management changes for 269 randomly selected NYSE and AMEX firms during the period 1963 to 1978. The authors find that the board of directors punishes poorly performing managers by forcing them out of the company, but they find no evidence of either positive or negative abnormal return relating to the announcement of a top management change.

Recent studies classify turnover events into different types based on either the type of the turnover (forced vs. voluntary) or the source of the replacement hire (internal vs. external). Huson, Malatesta, and Parrino (2004) identify all CEOs listed in the Forbes annual compensation survey from 1971 to 1995 who held their position for less than one year. From this list of CEOs, they construct their turnover sample, which consists of 1,344 CEO successions at large public firms from 1991 through 1994. They find that, for the average announcement period, abnormal return is positive and statistically significant. They also observe positive and statistically significant abnormal returns (for an average announcement period) for voluntary turnovers and forced turnovers with external replacement. The authors suggest that anticipated performance improvements are greater when the newly appointed CEO is an outsider, and conclude that investors generally view turnover announcements as good news. Adam and Mansi (2009) find a similar result: turnover events increase the value of the firm to shareholders. This increase in value is largest when the turnover is forced and when the replacement is an external hire.

The main theory behind these papers is the improved-management hypothesis. As pointed out by Huson, Malatesta, and Parrino (2004), the improved-management hypothesis posits that forced management turnover tends to increase managerial quality and, therefore, the expected firm performance. Under this hypothesis, a firm fires managers who perform badly and hires replacements of higher ability. An alternative explanation is that a firm fires a manager who is not a good match with the company and replaces them with someone who is a better fit. In either case, a turnover announcement signals impending improvement in company performance. Under this hypothesis, rational investors register such turnover announcements as good news, driving the stock price 
upwards.

However, other papers tell a different story.Dedman and Lin (2002) examine the market reaction to 251 CEO departure announcements for UK firms included in the FTSE All-Share Index over the period 1990-1995. They find that a CEO departure announcement generally induces a negative market reaction. This negative announcement reaction is especially significant in cases where no other news is released during the three-day period preceding the announcement. This finding suggests that investors view CEO turnovers as bad news. Among others, Ertugrul and Krishnan (2011) also suggest that the market reacts negatively to CEO turnover announcements. They classify turnovers as either "early dismissals" or "late dismissals" depending on whether the dismissal occurred subsequent to negative or non-negative industry-adjusted stock performance. They find the mean announcement-period return to have a statistically significant value of $4.63 \%$ for early CEO dismissal (forced turnover), with a statistically insignificant value of $0.09 \%$ for late dismissals. The median announcement-period return reveals similar results. In summary, the announcement effect for a CEO turnover event is either zero (late dismissals), or negative (early dismissals, or in other words, forced turnovers). The main theory behind these latter results is the over-assessed-ability hypothesis, as pointed out in Ertugrul and Krishnan (2011). Under this hypothesis, the market reaction to a forced CEO turnover is negative because the act of firing a CEO leads to the downward reassessment of the outgoing CEO's ability. That is, the firm's performance was overvalued because of the over-assessed ability of the outgoing CEO. Therefore, before any further change due to the potential improved management by the new CEO, the market price of the company should drop back to its true value.

\subsection{Main hypotheses}

Some findings in the literature are supported by the improved-management hypothesis, while other findings are supported by the over-assessed-ability hypothesis. We reconcile these two seemingly conflicting theories by adding an additional dimension to the analysis that accounts for the level of asymmetric information between a firm and its investors. This additional variable provides a bridge between the two hypotheses.

The starting point is that, when a firm hires a new CEO, they are usually chosen from many candidates or as part of a long-term succession plan. A firm chooses a CEO that best fits the company's needs. Thus, rational investors will always expect an incoming CEO to be capable of improving the firm's performance, or at least not making it worse.

When the level of asymmetric information is high, information about the firm is hidden from investors, who are therefore not able to observe the true ability of the outgoing CEO. In such an environment, an announcement that the CEO is being forced out will signal that the outgoing CEO's ability has been over-assessed and that the firm is performing poorly. Whenever investors learn that the firm was not doing as well as they had thought, the market reacts negatively. The over-assessed-ability hypothesis dominates in this case. 
In contrast, if the level of asymmetric information between investors and the company is low, investors will know when the outgoing CEO does a poor job, and there will be no reason to believe that the company has been overvalued at any time. In this case, forcing out an under-performing CEO will be good news to investors and the market should react positively. The improved-management hypothesis dominates in this case. Most CEO turnovers are voluntary. Voluntary turnovers usually follow CEO retirement due to age or health reasons. Voluntary turnover events can also take place when a CEO leaves to become the top manager of another company. Therefore, voluntary turnover announcements do not reveal poor firm performance, nor do they provide an dramatic update on the quality of the outgoing CEO. Since voluntary turnovers contain little new information, there is little that investors can learn from voluntary turnover announcements, the level of asymmetric information should not matter when the type of turnover is voluntary. Overall, the market reaction to a voluntary turnover should be either positive or negligible, and it is not related to information frictions.

Given the above, our main hypotheses are as follows ${ }^{1}$ :

1. When CEO turnover is forced, market reaction is based on the level of asymmetric information between the announcing firm and its investors. If the level of asymmetric information is high, the over-assessed-ability hypothesis dominates and the market reacts negatively. If the level of asymmetric information is low, the improved-management hypothesis dominates and the market reacts positively.

2. When the CEO turnover is voluntary, the market reaction is statistically insignificant or weakly positive, and it is unaffected by the level of asymmetric information.

\section{$3 \quad$ Data and Variables}

\subsection{Data collection and quantifying important measures}

We begin by searching for CEO turnover events announced between 2004 and 2014 among S\&P 1500 companies in the ExecuComp database. We look at companies in the S\&P 1500 because this index includes all stocks in the S\&P 500 (large capitalization), S\&P 400 (mid-capitalization) and S\&P 600 (small capitalization), and it covers 90\% of the market capitalization of all U.S. stocks. We identify the exact date for each turnover announcement using the Factiva News Database. Daily return data, trading volume, stock price, high-low spread and market data are obtained from the CRSP database. Accounting information and company headquarter locations are from the Compustat database. Daily Fama-French factors are from Kenneth French's website at Dartmouth. Analyst coverage, analyst forecasting error and analyst forecasting dispersion data are from the $\mathrm{I} / \mathrm{B} / \mathrm{E} / \mathrm{S}$ database.

\footnotetext{
${ }^{1}$ The main hypotheses are summarized in Table 2.
} 
Next, we determine whether a turnover announcement is made in a "clean" environment. Following Dedman and Lin (2002), we check for news releases of each company on the announcement date of their CEO's departure. We classify the announcement environment as "clean" if all announcements are related to the turnover event. In a clean environment, we can exclude cases where market reaction simultaneously accounts for other kinds of news such as the release of dividends. We determine the source of replacement hire (internal or external) through the incoming CEO's biography. The replacement hire is classified as external if the job title of CEO is the incoming CEO's first job within the company. Otherwise, it is classified as internal.

Following methodologies used in the literature (see Parrino (1997), Huson, Malatesta, and Parrino (2004), Adams and Mansi (2009), Intintoli, Zhang, and Davidson (2014) among others.). We develop an new algorithm to determine whether a CEO is being forced out from the company using the information provided by the press releases in the Factiva News Database. The turnover classification algorithm proceeds as follows:

1. If the press directly reports that the CEO is fired or forced out, then such turnover is classified as forced.

2. If the press reports that the CEO resigns or retires due to policy differences, pressure from stakeholders, or any unethical behavior, then such turnover is also classified as forced.

3. If the press reports that the CEO is retiring, and the departing CEO is above 60 years of age, then such turnover is classified as voluntary. If, however, the CEO is under 60 years of age and the retirement announcement is not made at least 6 months in advance, the turnover is classified as forced.

4. If the departing CEO is under 60 of age, the turnover event is classified as forced if the press does not report death, poor health, or acceptance of another position (internal or external to the firm) as the reason for the turnover.

5. After further searches of news or articles related to the events, turnovers classified as forced can be reclassified as voluntary if the departing CEO finds a comparable position elsewhere shortly afterwards or there is strong evidence that the departure is due to personal reasons unrelated to the company.

\subsection{Excluding interim succession}

Following the literature (Huson, Malatesta, and Parrino (2004), among others), We exclude turnover events related to M\&As or spin-offs. In addition, we also exclude turnover events in which the incoming $\mathrm{CEO}$ is an interim CEO.

An interim CEO is appointed by the board of directors when the turnover event takes the firm by surprise. Unanticipated CEO turnover can be either forced or voluntary. The board will not 
have sufficient time to choose a permanent CEO who is a good match for the firm and so they appoint an interim CEO.

Past research shows that a firm's performance is negatively impacted during the time that an interim CEO manages it. This negative impact is significant when the interim CEO is not the chairman of the company (Ballinger and Marcel (2010)). Investors do not treat this type of turnover as an upgrade in management. When a permanent CEO is appointed to replace the interim CEO after several months, the investors' beliefs about future firm performance may no longer be closely related to the original turnover event. Therefore, we exclude the 110 turnover events in our sample in which the incoming $\mathrm{CEO}$ is an interim CEO, which leaves a total sample size of 750 turnover events for the period 2004 to 2014 .

\subsection{Proxies for asymmetric information}

In this section, we describe the proxies used for asymmetric information. The literature contains many proxies for asymmetric information. One of the most widely used proxies is analyst coverage, which will be the main proxy used in our paper. Analyst coverage measures the number of analysts who follow a firm and forecast its earnings and returns. Analysts play an important role as information intermediaries between firms and investors in the capital market. The presence of analysts reduces market inefficiencies (Barth and Hutton (2004); Thomas (2002)) and serves as external monitoring of firms' managers (Brennan and Subrahmanyam (1995); Irvine (2003)), reducing information asymmetry (Kirk (2011)).

Analyst forecasting error and analyst forecasting dispersion are two alternative measures for asymmetric information (Krishnaswami and Subramaniam (1999)). In particular, analyst forecasting error measures the gap between analyst forecasts and true value. The information that analysts use is from the market. As a result, forecasting errors increase with higher levels of asymmetric information between investors and firm managers. Analyst forecasting dispersion is measured by the standard deviation of forecasts. Disagreement amongst analysts is an indication of lack of information available to them. Therefore, this standard deviation of analyst forecasts can be another proxy for asymmetric information levels.

Firm size is another commonly used measure for the level of asymmetric information. Relative to small firms, large firms are expected to have higher levels of information disclosure, attract more investor attention, and have lower levels of asymmetric information.

Another alternative measure for asymmetric information that we use is a dummy variable that indicates whether or not a company is a member of the S\&P 500. Barana and King (2014), among others, suggest that the level of asymmetric information is lower for firms included in the S\&P 500 Index. The authors find a significant decrease in information asymmetry following index inclusions. They also find strong support for an increase in information asymmetry after deletion events.

Our last proxy for asymmetric information is the geographic distance between the company headquarters and the 21 largest cities in the United States. Investors are generally more interested 
in local companies and can obtain information for those companies more readily. Therefore, a firm that is located far away from the 21 largest cities will have higher levels of asymmetric information between the company and its investors (Ivkovic and Weisbenner (2005); Cziraki, Mondria, and Wu (2017).

\subsection{Variables Construction}

In this section, we explain how we construct the variables used in the paper.

- Analyst coverage: Since each analyst reports only one forecasting result, we count the total number of estimations on earnings per share for the next fiscal year of a company in the last month before the turnover event as the number of analysts following that company. To smooth the data, we use $\ln (1+$ number of forecasts $)$ as the measure of analyst coverage in this paper.

- Analyst forecasting error: Following Krishnaswami and Subramaniam (1999), we measure forecasting error as the ratio of the absolute difference between the mean or median of the forecast earnings and the actual earnings per share to the price per share on the last day of the estimation window:

$$
\text { AnalystForecastingError }=\frac{\mid \text { AverageForecast-ActualEPS } \mid}{\text { Price }},
$$

where AverageForecast can be either the mean or median of the analyst forecastings.

- Analyst forecasting dispersion: This variable is measured as the standard deviation of all earnings forecasts made in the last month before the turnover event.

- Size: This variable is measured using the market capitalization of the company, which is calculated by multiplying the number of outstanding shares by the price per share. We take the natural $\log$ of this market capitalization to smooth the data.

- Distance between firm headquarters and nearest major city: Following Coval and Moskowitz (1999) and Cziraki, Mondria, and Wu (2017), we calculate the geographic distance between a firm's headquarters and each of the 21 largest cities in the U.S. We use latitude and longitude data for the corporate headquarters and the 21 most populous cities from the U.S. Census Bureau's Gazetteer Files. For each big city, the geographic distance is calculated by the following formula:

$$
\begin{aligned}
& D_{i j}=\arccos \left\{\cos \left(l a t_{i}\right) * \cos \left(l_{l o n_{i}}\right) * \cos \left(l_{a t}\right) * \cos \left(l_{j} n_{j}\right)\right. \\
& \left.+\cos \left(l a t_{i}\right) * \sin \left(l o n_{i}\right) * \cos \left(l a t_{j}\right) * \sin \left(l n_{j}\right)+\sin \left(l a t_{i}\right) * \sin \left(l a t_{j}\right)\right\} * \frac{2 \pi R}{360},
\end{aligned}
$$

where $D_{i j}$ is the distance between head-quarter of firm $i$ and city $j$; lat and lon are latitudes and longitudes (measured in degrees) of company headquarter $i$ and city $j$; $R$ is the radius of the earth (about $6378 \mathrm{~km}$ ); The smallest of the distance $D_{i j}$ value is chosen to construct our distance variable for each firm $i$. 
- Book-to-market ratio: This variable is the ratio of the common stock's book value to market capitalization on the firm's last fiscal quarter end date before CEO turnover.

- Institutional ownership: This variable measures the percentage of firm shares owned by institutional investors. It is calculated by taking the ratio of the number of shares owned by institutional investors over total shares outstanding.

- Liquidity: Following Drake, Roulstone, and Thornock (2012), we use the bid-ask spread and stock turnover as a measurement for liquidity. In particular, the bid-ask spread is a measure of the difference between daily high and low prices. Stock turnover is measured by the daily trading volume divided by the number of common shares outstanding.

\subsection{Empirical methodology}

We use event studies to analyze market reaction to CEO turnover announcements. In particular, we use cumulative abnormal return (CAR) to represent market reaction during the announcement period. We estimate parameters for a base return model using return data in the estimation window that is unaffected by the event. We use day 50 to 300 as our estimation window. The model we use is the standard Fama-French three-factor model:

$$
R_{i, t}=R_{f}+\beta_{1} *\left(R_{m}-R_{f}\right)+\beta_{2} * S M B+\beta_{3} * H M L+\varepsilon,
$$

where $R_{i, t}$ is the return for stock $i$ on date $t ; R_{f}$ is the risk free rate; $R_{m}$ is the market return; we use CRSP value-weighted return as our market return; $S M B$ is the excess return on small capital stocks relative to large capital stocks; $H M L$ is the excess return on high book-to-market ratio stocks compared to low $\mathrm{B} / \mathrm{M}$ ratio stocks; $\varepsilon$ is the estimation error, with $E[\varepsilon]=0$.

Using estimated parameters from the model, we predict the estimated return for each stock in the event window. The abnormal return (AR) is the difference between the actual return and the estimated return. Summing up all the abnormal returns in the event window, we obtain the cumulative abnormal return (CAR) for stock $i$.

$$
A R_{i, t}=R_{i, t}-E\left[R_{i, t}\right] \quad C A R_{i}\left[\tau_{1}, \tau_{2}\right]=\sum_{t=\tau_{1}}^{\tau_{2}} A R_{i, t}
$$

\section{Empirical Results}

\subsection{Descriptive statistics}

In this section, we analyze the summary statistics for our sample of CEO turnover events from 2004 to 2014 . There are a total of 750 turnover events in our sample. We classify 125 of these events as forced and 625 as voluntary. More than half of all CEO turnover events take place in a clean announcement environment, 83 of which are forced events and 401 are voluntary. The average 
number of analysts following a company in the whole CEO turnover firm sample is 11 in general and 10 in a clean environment. See Tables B1 and B2 of the for more details.

In Table 1, we report the mean value for variables that measure company statistics (after sorting the sample into three groups based on the number of analysts who follow the company). We find that firms with larger market capitalization tend to have more analyst coverage. This relationship may exist because larger firms are more attractive to analysts. We find a negative relationship between the number of analysts who follow a firm and a firm's book-to-market ratio. It seems that analysts are more interested in following companies that have greater growth opportunities. We also find that companies with low analyst coverage tend to be located further from major cities than those with high analyst coverage. This result is not surprising as investors tend to be more interested in local firms. Companies located far away from the major cities attract fewer investors and, therefore, fewer analysts.

[Insert Table 1]

We also divide our sample into quantiles by the level of analyst coverage. For companies who are followed by fewer than 10 analysts, the proportion of turnover-announcing firms listed in the S\&P 500 Index (SP events) is smallest (16.5\%). As analyst coverage increases (and asymmetric information decreases), the proportion of SP events increases. In the quantile with lowest asymmetric information (number of analysts is greater than 20), the proportion of SP events is the highest. These results do not change when we look at the clean-environment subsample. This is consistent with the finding that analysts care more about firms with larger market capitalization. This is also consistent with the literature showing that firms listed in the S\&P 500 have a lower level of asymmetric information than firms that are not in the index (Barana and King (2014)).

Figures 1 and 2 plot the daily CARs for voluntary and forced turnovers around the announcement date for days 20 to +20 . From these graphs, it is clear that while there is no significant market reaction following a voluntary turnover, there is a negative market reaction following a forced turnover. But do forced turnovers necessarily affect stock prices negatively The answer is no! Figures 3 and 4 depict the market reaction for forced turnover announcements in different subsamples based on the level of analyst coverage. The market reacts negatively if a company's analyst coverage is low. Market reaction is more positive for companies that are covered by more analysts. We will explain this in more detail in the next few sections.

[Insert Figure 1 to 4$]$

\subsection{CAR analysis}

In this section, we study the behavior of the cumulative abnormal return (CAR) around the date of the turnover announcement. 


\subsubsection{CAR for event window for days $[-1,+1]$}

First, we look at the CAR from the day before the announcement date to the day after the announcement date (event window days 1 to +1 ). We use a standard t-test to test whether the mean of the CAR is significant or not.

$$
t=\frac{A C A R\left[\tau_{1}, \tau_{2}\right]}{S t d} \sim N(0,1)
$$

where $A C A R\left[\tau_{1}, \tau_{2}\right]=\overline{C A R}\left[\tau_{1}, \tau_{2}\right]$ measures the mean of the CARs over the event window $\left[\tau_{1}, \tau_{2}\right]$; $S t d$ is the sample standard deviation of the CARs over the event window $\left[\tau_{1}, \tau_{2}\right]$; The event window $\left[\tau_{1}, \tau_{2}\right]$ here covers days $[-1,+1]$, where day 0 is the day that the company announces the turnover event.

The results are reported in Table 3 . We find that when the level of asymmetric information is low (there are more than 20 analysts covering the firm), the ACAR is significantly positive in general. Looking exclusively at forced turnover events, we find a negative, although insignificant, ACAR when the companies are covered by fewer than 10 analysts, and a positive ACAR when the companies are covered by more than 10 analysts. The results are stronger in the clean environment.

[Insert Table 3]

Other significant results for ACAR are not found in the event window of days 1 to +1 . This lack of significant results may be due to the event window being too small. The event window needs to be large enough to capture any information leakage prior to the announcement. Also, it takes time for information to travel through the market after an announcement. In the next subsection, we determine an effective event window.

\subsubsection{Abnormal trading volume and event window determination}

To find the most effective event window, we test for abnormal trading volume around the turnover announcement. Following Jarrel and Poulsen (1989) and Bajo (2010), we calculate the normalized abnormal volume (NAV) to capture how the trading volume around the turnover announcement date deviates from the normal trading activity. The NAV for stock $i$ on day $t$ is computed as:

$$
N A V_{i t}=\frac{T V_{i t}-\mu_{i t}}{\sigma_{i t}}
$$

where $\mu_{i t}=\frac{1}{66} \sum_{t=1}^{66} T V_{i t}, T V_{i t}$ is the trading volume for stock $i$ on day $t$ (computed as natural $\log$ of $(1+$ the trading volume $)) ; \mu_{i t}$ and $\sigma_{i t}$ are the mean and standard deviation of trading volume in the 66 day window immediately prior to the observation.

We then test whether this NAV is significant across all firms for each day based on different subsamples. The result is shown in Table 3.

[Insert Table 4] 
We find a significant positive abnormal trading volume before the announcement date on day -4 and day -1 , and after the announcement date from days 0 to +5 , and days +7 to +9 in the general environment. However, in the clean environment, day -4 and day +5 no longer have a significant abnormal volume. Focusing only on forced turnovers, there is significant negative trading volume before the announcement date on days -7 to -5 . After the announcement date, a positive and significant abnormal trading volume is found on days 0 to +4 , and also on day +7 . When we look at the clean environment, forced turnovers have a significant negative abnormal trading volume on day 6 , and significant positive abnormal trading volume on days 0 to 3 . These findings suggest that the market needs time to fully react to the turnover announcement. Additionally, information leakage prior to turnover announcements induces significant abnormal trading volume on the days leading up to the actual announcement. Since there is no consistent result through all subsamples for daily abnormal trading volume, there is no event window that perfectly fits all subsamples.

We next look at weekly abnormal trading volume. Following the above methodology, we use weekly average trading volume (WATV) as our starting point. We calculate the deviation of this WATV to the mean WATV in the 20 -week window immediately prior to the observation, scaled by the standard deviation:

$$
W A A T V_{i, t}=\frac{W A T V_{i, t}-\mu_{i, t}}{\sigma_{i, t}}
$$

where

$$
\mu_{i, t}=\frac{1}{20} \sum_{t=1}^{20} W A T V_{i, t}
$$

Here, $W A A T V_{i, t}$ is the weekly abnormal average trading volume for stock $\mathrm{i}$ in week $\mathrm{t}$. The result is shown in Table 5 . We find a positive and significant (both statistically and economically) abnormal trading volume in week 0 (i.e. the week that the company announces its CEO turnover) as well as in week +1 . This result holds across all subsamples. Thus, we can choose weeks 1 to +1 as our event window. We use this event window for the remainder of this paper. We include week 1 in the event window because for companies that announce a CEO turnover on Monday, we want to capture the effect from potential information leakage before the turnover announcement.

\section{[Insert Table 5]}

\subsubsection{CAR for event window for weeks $[-1,+1]$}

Similar to Section 4.2.1, we employ a t-test on the ACAR over an event window for weeks 1 to +1 to examine market reaction to CEO turnover announcements based on different subsamples. The test results are shown in Table 6.

[Insert Table 6] 
As reported in Table 6, we find significant negative ACARs for forced turnover events when we restrict to subsamples of firms covered by fewer than 10 analysts, in both general and clean environments. In particular, ACAR is $4.09 \%$ in general and $3.89 \%$ in clean environments, both of which are statistically and economically significant. This finding suggests that, if the level of asymmetric information is high (i.e. low analyst coverage), the over-assessed-ability hypothesis dominates; investors treat such turnover announcements as bad news. In addition, we find nonstatistically significant positive ACARs for forced turnovers in subsamples with higher analyst coverage; the improved-management hypothesis dominates in this case.

We also find that companies have positive abnormal returns if turnover is voluntary. This result is stronger in the clean environment. However, regarding economic significance, the magnitude for abnormal returns on voluntary turnover events is relatively small, ranging from $0.61 \%$ to $1.68 \%$. This result holds for all subsamples, regardless of the level of analyst coverage, and suggests that the market reaction is unrelated to the level of asymmetric information when the type of turnover is voluntary. This finding is consistent with our hypothesis (stated in Section 2.2).

\subsection{Baseline results}

Section 4.2 shows that the level of analyst coverage affects the abnormal return generated by CEO turnover events. In this section, we show how this analyst coverage affects the CARs.

Our baseline model is as follows:

$$
\begin{aligned}
\operatorname{CAR}_{i}\left[w_{-1}, w_{1}\right]= & \alpha+\beta_{e} \text { Ext }_{i}+\beta_{f} \text { Forced }_{i}+\beta_{a} \text { Anacov }_{i}+\beta_{a e} \text { Anacov }_{i} * \text { Ext }_{i}+\beta_{\text {af }} \text { Anacov }_{i} * \text { Forced }_{i} \\
& +\beta_{6} \text { InstOwnership }_{i}+\beta_{7} \text { Size }_{i}+\beta_{8} \text { BMratio }_{i}+\beta_{9} \text { Spread }_{i}+\beta_{10} \text { Turnover }_{i}+\epsilon_{i}
\end{aligned}
$$

where $C A R_{i}\left[w_{-1}, w_{1}\right]$ is the cumulative abnormal return for CEO turnover event $i$ from week -1 to +1 around the announcement date; $E x t_{i}=\{0,1\}$ indicates whether or not turnover event $i$ uses an external hire as replacement; Forced $_{i}=\{0,1\}$ indicates whether turnover event $i$ is a forced turnover; Anacov $_{i}=\ln (1+$ AnalystFollowing $)$ measures analyst coverage for a company that announces the turnover event $i$, as a proxy for the level of asymmetric information between the company and its investors; $\left\{\right.$ InstOwnership $_{i}$, Size $_{i}$, BMratio $_{i}$, Spread $_{i}$ and Turnover $\left._{i}\right\}$ are control variables that measure the characteristics of the company involved in the turnover event $i$; InstOwnership represents the proportion of shares owned by institutional investors; Size refers to the market capitalization of the company; BMrario is the ratio of the company's book value to market capitalization; Spread refers to the high-low price difference for the bid-ask spread; Turnover is calculated as trading volume divided by total shares outstanding.

In this model, we use CAR to represent market reaction to turnover events as our dependent variable. The purpose of this model is to analyze how the type of turnover and analyst coverage affect market reaction, separately and together. We are interested in the coefficients of the variables Forced, Anacov and Anacov ${ }^{*}$ Forced, which are $\beta_{f}, \beta_{a}$, and $\beta_{a f}$, respectively. The regression results with robust standard errors are reported in Table 7 . 
[Insert Table 7]

In particular, Forced is negatively related to CAR, and Anacov*Forced is positively related to CAR. Both are significant at the $99 \%$ confidence level in general as well as for the clean environment subset. However, Anacov is not significant.

Table 7 also reports the economic significance of the variables. The coefficient for forced turnover is $-13.9 \%$ in the general environment, which is significantly different from zero. This finding means that, if the company announces a forced turnover, the three-week market reaction (CAR) around the announcement week, without considering other factors that may affect the market, will be $-13.9 \%$. In other words, the company loses $13.9 \%$ of its market value in the three-week event window around the announcement compared to its normal stock baseline value performance. This loss is $13.6 \%$ in the clean environment subset where there are no other news announcements around the time of the turnover announcement. The cross effect of analyst coverage and forced turnover suggests that an increase in the level of information exposure can offset the negative effect of the forced turnover announcement. The coefficient $\beta_{a f}$ is $4.96 \%$ in the general environment, which is significantly different from zero. This coefficient suggests that, for each standard deviation increase in the log analyst coverage, the cumulative abnormal return (CAR) between week -1 and week +1 around the turnover announcement is increased by a magnitude of $3.67 \%(4.96 \% * 0.7403)$. This positive effect is $3.45 \%(4.82 \% * 0.7160)$ if the announcing environment is clean. The evidence above suggests that a company would require an analyst coverage of 15 or higher to counter the negative effect of a forced turnover, compared to a voluntary turnover.

These findings suggest that forced turnover in general is bad news to investors. However, with sufficiently high analyst coverage, investors would be able to anticipate the CEO turnover and there would be little re-assessment of the ability of the outgoing CEO, so the market may react positively to this forced turnover news. This result holds in both general and clean environments. In addition, Anacov itself is not significant, which suggests that the level of asymmetric information affects the CAR only when turnover is forced.

\subsection{Embellishing information}

The above sections show that a market will react negatively to forced CEO turnover announcements if the level of asymmetric information between a company and the market is high. Therefore, companies with low analyst coverage have an incentive to represent forced turnovers in a more positive light, and they may attempt to convince the public that the announced turnover is voluntary. For example, these firms may announce that the outgoing CEO is retiring or state that it is a mutual agreement. Note that the company cannot embellish the forced aspect if the outgoing CEO is found to be involved in illegal or unethical activities. Also, companies only embellish turnover details when the turnover is forced.

In this section, we test the effect of this embellishing behavior. We define the company as embellishing information if the turnover is classified as forced according to the guidelines outlined 
in Section 3.1 but the company announces it as voluntary. Recall that we classify a turnover event as forced if the departing CEO is under 60 years old and the announcement does not report the reason for retirement or resignation as death, poor health, or the acceptance of another position (within or outside the company). A turnover event is also classified as forced if the departing CEO is under 60 and the press reports that he is retiring but the announcement is not made at least six months in advance. Panel A of Table 12 shows the number and fraction of companies that attempt to embellish the "forced" aspect in the different analyst coverage quantiles. The proportion of firms embellishing information is highest in the quantile of firms with analyst coverage below 10, and lowest when analyst coverage is greater than 20 .

\section{[Insert Table 12]}

We also look at how the behavior of embellishing the forced turnover details contributes to the market reaction of the turnover announcement using the following model:

$$
C A R_{i}[w(-1), w(+1)]=\alpha+\beta_{1} \text { Hide }_{i}+\beta_{2} \text { Control }_{i}+\text { error },
$$

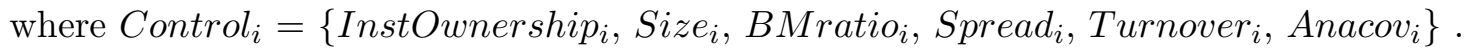

We run this regression in sub-samples based on the level of analyst coverage. The regression results with robust standard errors are reported in panel B of Table 12.

As reported in the table, we find that when firm analyst coverage is low (below 10), and thus the level of asymmetric information is high, the behavior of embellishing information contributes positively to the market reaction (6.48\% in the general environment) and is statistically and economically significant. In contrast, when firm analyst coverage is high (greater than 10), the effect of embellishing forced turnover information is insignificant. This is because even if these companies attempt to embellish the "forced" aspect, they may fail due to the high level of information exposure. On the other hand, when the announcement is made without other news (in a clean environment), the effect of embellishing the "forced" aspect is smaller and less significant. This is because in the absence of other news to divert investor attention, investors could investigate turnover announcements in greater detail and the hidden aspects of forced turnovers are more easily revealed.

\section{[Insert Figure 7 and 8 ]}

Figures 7 and 8 show how firms' embellishing behavior affects market reaction for firms with different levels of analyst coverage in the general and clean environments. It is clear that such behavior contributes positively to the market reaction for firms with low analyst coverage, and the effect is not obvious for firms with high analyst coverage.

In general, it is clear that companies with low analyst coverage benefit from embellishing the "forced" aspect when forcing out their incumbent CEO. This evidence is consistent with our baseline result suggesting that forced turnover is bad news to firms with higher levels of asymmetric information. 


\section{Robustness check}

In this Section, we check the robustness of our baseline results using different subsamples and alternative proxies of information asymmetry.

\subsection{Subsample splits by firm size}

It is commonly agreed that large firms tend to attract more analyst coverage. Because of this high correlation between firm size and analyst coverage, one may consider a counter-hypothesis: it may be the size of the company rather than the effect of the level of asymmetric information that is driving our baseline result. To mitigate such concern, we perform a robustness test in this subsection. We divide our total sample into two parts based on the size of the company (market capitalization). We then test our baseline model in the subsample consisting of only large firms. If our baseline result is really due to the effect of firm size, we should not observe any significant effect from our key variables. The regression output is also reported in Table 14.

From the table, we can see that in this subsample of large firms, the coefficient for forced turnover remains negative and significant, both statistically and economically. Furthermore, the coefficient for the cross effect of analyst coverage and forced turnover also remains positive and significant. The magnitudes are similar, and the results hold in both general and clean environments. We therefore conclude that our theory remains qualitatively consistent even after restricting to this subsample of only large firms.

\subsection{Controlling for corporate governance}

One may also be concerned that the different stock market reactions we observed in the estimation are not driven by information asymmetry but by firm's governance before the CEO turnover announcement. Managers in firms with poor corporate governance might engage in empire building-investing more projects to increase the firm size and increase personal benefit. Intuitively, it would be more costly for new managers appointed by such firms get rid of those projects. Hence these firms will suffer more negative market reactions. To mitigate such concern, we rerun our baseline estimation controlling for three proxies for corporate governance. The regression output is also reported in Table 15. In the table, Governance $i$ is one of $\left\{E-\right.$ index $_{i}$, WeakGov $_{i}$ and $\left.A T I_{i}\right\}$, measures the level of corporate governance. $E-i n d e x_{i}$ is the number of 6 managerial entrenchement provisions that firm $i$ has (Bebchuk, A., and Ferrell (2009)); WeakGovi takes a value 1 if the firm's E-index is above the median (E-index $>3$ ), and 0 otherwise; $A T I_{i}$ is the number of 3 antitakeover provisions that firm $i$ has (Cremers and Nair (2005)). The estimation results after controlling for corporate governance are quantitatively similar to our baseline results. 


\subsection{Subsample splits by firm performance}

Another concern is that the different stock market reactions might be driven by firm's different performance before the CEO turnover announcement. Investors for firms which under-performed before the turnover announcement might be more likely to treat the forced turnover as a good news, hence such firms might be more likely to experience a positive stock market reaction. Whereas investors for over-performed firms might tend to treat the forced turnover as a bad news(eg. the result of internal conflicts within the management team). Thus these firms may be more likely to experience a negative stock market reaction. To test whether our results are actually driven by firms' different performance before the CEO turnover announcement, we split our sample into two subsamples based on firm performance before the announcement and rerun our baseline estimation for each subsample. The regression output is also reported in Table 16. This table reports our baseline results in sub-samples of firms that underperformed or overperformed the industry before the CEO turnover announcement. Firms are classified as underperformed (overperform) the industry if the last year performance is below (above) the industry median for that year. Industries are classified based on the Fama-French 12 industry classification method. Columns 1, 2, 5 and 6 use average monthly stock return to measure the firm performance. Columns 3, 4, 7, and 8 use scaled monthly return (average monthly return scaled by the annual standard deviation) to measure the firm performance. Columns 1, 3, 5 and 7 report the results for firms that overperform the industry. Columns 2, 4, 6 and 8 report the results for firms that underperform the industry. The estimation results are very similar in both samples, suggest that the different stock market reactions do not simply arise from different firm performances before the CEO turnover announcement.

\subsection{Alternative proxies for information asymmetry}

One may argue that analyst coverage may represent something other than the level of asymmetric information. For example, companies with high analyst coverage usually also have greater market attention and are more well-known than companies with low analyst coverage. As we know, wellknown companies can attract managers of higher ability, while lesser-known companies cannot. Consequently, once a turnover is announced by a well-known company with high analyst coverage, investors may expect the old CEO to be replaced with a better one who can improve firm performance, which would raise the stock price. Since a company with low analyst coverage is not expected to replace the old $\mathrm{CEO}$ with a better manager, the stock price would decrease in response to a turnover announcement.

In this subsection, we consider alternative proxies for asymmetric information (size, analyst forecasting error based on the mean and median forecast, analyst forecasting dispersion, S\&P Index

code, and distance) to further check the robustness of our baseline result. The correlations between these proxies of asymmetric information are reported in Table 8. We find that analyst coverage is positively correlated with size and S\&P Index code, but negatively correlated with other measures. This finding confirms that analyst coverage, size, and S\&P 500 membership are negatively related to 
the level of asymmetric information, while analyst forecasting error, analyst forecasting dispersion, and distance between company headquarters and the nearest major city are positively related to the level of asymmetric information. The magnitude of correlation is 0.6549 between size and analyst coverage, indicating that larger companies attract greater analyst coverage. Inclusion in the S\&P 500 is highly correlated with firm size, which is as expected since inclusion in the S\&P 500 Index is based on market capitalization. However, the correlations between (1) analyst coverage and the forecasting error, (2) analyst coverage and forecasting dispersion, and (3) analyst coverage and distance are small in magnitude. This implies that these additional proxies might capture different aspects of asymmetric information between firms and investors. If we can find evidence that supports our hypothesis using these alternative proxies, the counter-hypothesis stated at the beginning of this section is unlikely to be true.

\section{[Insert Table 8]}

The revised model in this sub-section as follows:

$$
\begin{aligned}
C A R_{i}\left[w_{-1}, w_{1}\right]= & \alpha+\beta_{e} \text { Ext }_{i}+\beta_{f} \text { Forced }_{i}+\beta_{p} \text { Prox }_{i}+\beta_{p e} \text { Proxy }_{i} * \text { Ext }_{i}+\beta_{p f} \text { Proxy }_{i} * \text { Forced }_{i} \\
& +\beta_{6} \boldsymbol{X}_{i}+\epsilon_{i}
\end{aligned}
$$

where $\boldsymbol{X}_{i}=\left\{\right.$ InstOwnership $_{i}$, Size $_{i}$, BMratio $_{i}$, Spread $_{i}$, Turnover $_{i}$, Anacov $\left._{i}\right\}$ are control variables; Proxy $i$ is one of $\{$ Size, Mean Forecasting Error, Median Forecasting Error, Forecasting Dispersion, SEP index code, Distance $\}$, which is the proxy for the level of asymmetric information; All other variables are as seen in the original model in Section 4.3. Again, the coefficients of interest

are $\beta_{e}, \beta_{f}$, and $\beta_{p f}$. The regression results with robust standard errors are reported in Tables 9 and 10.

[Insert Table 9 and 10]

\subsubsection{Size}

Column 1 of Tables 9 and 10 reports the regression results when using size as the proxy for asymmetric information. The results are very similar to that found in Section 4.3 when using analyst coverage as the proxy. The coefficient on the forced turnover dummy is negative and significant, both statistically and economically ( $20.28 \%$ in general and $24.64 \%$ in a clean environment, both at a $99.9 \%$ significance level). This finding suggests that forced turnover is bad news and negatively affects abnormal returns during the announcement period. At the same time, the cross effect of forced turnover and size is positive and significant $(2.24 \%$ in general and $2.88 \%$ in the clean environment, both at a $99.9 \%$ significance level). This finding suggests that when a CEO turnover is forced, each additional unit of log market capitalization increases abnormal returns by a magnitude of $2.24 \%$ in general and $2.88 \%$ in the clean environment. 
Combining the effects, we obtain results that are similar to the baseline results in Section 4.3. If the size of the company is small (with a high level of asymmetric information), the market reacts negatively to news of a forced turnover to adjust for previous over-assessment of the outgoing CEO's ability. If the size of the company is large (a low level of asymmetric information), the market reacts positively to a forced turnover because the expectation of improved incoming management dominates in this case.

\subsubsection{Analyst forecasting error}

From columns 2 and 3 of Tables 9 and 10, we find that forced turnovers contribute negatively to CARs, and the effect is statistically and economically significant in both general and clean environments. By the assumption stated in Section 3.3, analyst forecasting error is positively related to the level of asymmetric information. Therefore, the negative coefficient for Proxy*Forced suggests that the cross effect of information asymmetry and forced turnover is negative. In addition, the negative cross effect, although statistically insignificant, is found in the clean environment. These findings are consistent with our hypothesis and also hold for the median forecasting error proxy. The absolute value of the correlation between forecasting error and analyst coverage, however, is low, implying that these two variables might represent different aspects of asymmetric information between a firm and the market.

\subsubsection{Analyst forecasting dispersion}

Column 4 of Tables 9 and 10 report the findings obtained from using analyst forecasting dispersion as a proxy for the level of asymmetric information. Although insignificant, the magnitude of the coefficients for forced turnover and the cross effect of forced turnover and forecasting dispersion are both negative. This finding confirms that forced turnover is bad news in general, and that asymmetric information also contributes negatively to market reaction when turnover is forced. We defer the discussion for the reason of the statistical insignificance to Section 4.5.

\subsubsection{S\&P Index code}

As shown in column 5 of Tables 9 and 10, the magnitude of the effect of forced turnover on CARs is $5 \%$ in general and $5.42 \%$ in the clean environment, and the magnitude of the cross effect of forced turnover and the indicator of whether the company belongs to the S\&P 500 Index is $5.65 \%$ in general and $7.97 \%$ in the clean environment, all of which are statistically and economically significant. This suggests that if the company is included in the S\&P 500 Index, the announcement

effect for a forced turnover will be similar to that of a voluntary turnover, or may even generate a more positive reaction (the improved-management hypothesis dominates). If the company does not belong to the S\&P 500, a forced turnover will have a significantly negative effect on its stock price (over-assessed-ability hypothesis dominates). These findings further confirm our hypothesis. 


\subsubsection{Distance}

Column 6 of Tables 9 and 10 reports a significantly negative effect for the Distance*Forced term. This implies that if turnover is forced, the market reacts more negatively to firms with headquarters situated further away from a major city. This result is stronger in the clean environment subset. The magnitude is small because the variable Distance is measured in kilometers, and the effect represents the return per $\mathrm{km}$. The effect of distance is still economically significant.

\subsection{The Effect of asymmetric information in voluntary and forced turnovers}

One may argue that the above section only analyzes the difference of the effect of asymmetric information for forced turnovers relative to voluntary turnovers, but not the effect for a forced turnover in itself. Therefore, the effect of asymmetric information may not necessarily be negative and significant for forced turnovers. In fact, a positive effect on voluntary turnover plus an insignificant effect on forced turnover can also cause the difference to be negative. In this section, we want to check whether the negative incremental effect of information asymmetry on forced turnovers over voluntary turnovers is from the negative effect on forced turnovers or the positive effect on voluntary turnovers. We analyze how asymmetric information affects market reaction if turnover is either forced or voluntary. In particular, we apply the following model to subsamples that consist only of voluntary or forced turnovers.

$$
C A R_{i}[w(-1), w(+1)]=\alpha+\beta \text { Proxy }_{i}+\text { error },
$$

where Proxy $y_{i}$ is one of $\{$ Analyst Coverage, Size, Mean Forecasting Error, Median Forecasting Error, Forecasting Dispersion, SEP Index code, Distance $\}$ and measures the level of asymmetric information as described in Section 3.3.

Here, $\alpha$ represents the effect of forced or voluntary turnover on CARs, and $\beta$ represents the effect of the level of asymmetric information on CARs. The results with robust standard errors are reported in Table 11. Panels A and B report the results in subsamples containing only forced turnovers. Panels $\mathrm{C}$ and $\mathrm{D}$ report the results in subsamples containing only voluntary turnovers. Panels A and C report results in the general environment. Panels B and D report results in the clean environment.

$$
\text { [Insert Table 11] }
$$

\subsubsection{Analyst coverage}

Analyst coverage is the proxy we use in our baseline model. Figures 5 and 6 show the relationship between the firm analyst coverage and market reaction to an announcement of forced CEO turnover, both for general and clean environments. These graphs show a clear upward trend of CAR as the number of analysts following the company increases. The fitted line touches zero when the number of analysts is about 13 in the general environment or 12 in the clean environment. 
Table 11 shows the magnitude of the effects in forced turnovers. The effect of analyst coverage is $5.52 \%$ in the general environment and $4.53 \%$ in the clean environment. The constant term shows that the effect of forced turnover itself is $14.51 \%$ in general and $11.54 \%$ in the clean environment. All coefficients are statistically and economically significant. This suggests the market will react negatively to news of a forced turnover. However, if the company has analyst coverage of 12 or more, the announcement of a forced turnover should not induce a negative market reaction.

In a falsification test, we find the effect of analyst coverage is insignificant in the subsample that consists only of voluntary turnovers, as shown in the first column of panels C and D in Table 11. This suggests that the level of asymmetric information does not matter when turnover is voluntary. Combining the positive and significant effect of analyst coverage in the forced turnover subsample with the insignificant effect in the voluntary turnover subsample, we get a positive significant effect for the difference between forced and voluntary turnover, which is the result shown in Section 4.3.

\subsubsection{Size}

The result here is similar to the result discussed in Section 4.5.1. Forced turnover itself is bad news. However, this negative effect is smaller in large companies, and if the company is large enough, the stock may yield a positive abnormal return. Again, the effect of information on voluntary turnover is insignificant.

\subsubsection{Analyst forecasting error}

From columns 3 and 4 in panels $\mathrm{C}$ and $\mathrm{D}$ of Table 11, we can see that voluntary turnover itself shows a positive and significant abnormal return, but the effect of the forecasting error is insignificant.

However, if turnover is forced, the story is different. The negative and significant coefficient of the forecasting error shown in columns 3 and 4 in panels $\mathrm{A}$ and $\mathrm{B}$ suggests that as forecasting error increases, the market will react more negatively to the turnover event. In particular, for each unit increase in forecasting error, the CAR will decrease by a magnitude of $2.9 \%$, both in general and the clean environment. This finding confirms that asymmetric information contributes negatively to the abnormal return of a company during the announcement period of a forced turnover. The result is similar if we use median instead of mean forecasting error.

\subsubsection{Analyst forecasting dispersion}

The story here is similar to the results from using analyst forecasting error as the proxy for asymmetric information. The negative and significant coefficient on forecasting dispersion suggests that, for each unit increase in analysts forecasting dispersion, the thrree-week CAR of a forced turnover is diminished by a magnitude of $3.33 \%$ in general and $3.38 \%$ in the clean environment. Forecasting dispersion also contributes negatively to CAR when turnover is voluntary, but the magnitude is slightly smaller than what is found when the turnover is forced $(-2.87 \%$ in general and 
$-2.04 \%$ in the clean environment, both statistically and economically significant). When the effect of forecasting dispersion is significantly negative in both forced turnover and voluntary turnover subsamples, the difference can be insignificant. This can explain why the regression result shows that the effect of Forced ${ }^{*}$ Analyst Forecasting Dispersion is insignificant in Section 4.4.3.

\subsubsection{S\&P Index code}

When the turnover is forced, companies have negative CARs, and the effect of being included in the S\&P 500 Index is positive. As shown in column 6 of Table 11, the magnitude of the forced turnover effect itself is $-3.95 \%$ in general and $-3.84 \%$ in the clean environment, both of which are statistically and economically significant. The effect of being included in the S\&P 500 Index is 5.32\% in general and $8.12 \%$ in the clean environment, both of which are also statistically and economically significant. When the turnover is voluntary, however, companies have positive abnormal returns, and the effect of being included in the S\&P 500 Index is close to zero and insignificant. These findings suggest that the level of asymmetric information does not matter when the turnover announcement contains little new information (voluntary turnover); however, if turnover is forced, S\&P 500 companies will have positive abnormal returns and companies not included in the S\&P 500 Index will have negative abnormal returns.

\subsubsection{Distance}

Column 7 in Table 11 also reports how the distance of a firm's headquarters from the nearest major city affects market reaction for voluntary and forced turnovers. Similar to other proxies, the effect of distance is close to 0 when turnover is voluntary. The effect of distance is negative and significant in the subsample that consists only of forced turnover, with magnitude of 0.0000714 in general and 0.0000779 in the clean environment. This suggests that a company that announces the firing of its CEO can expect its stock price CAR to decrease by 71 basis points for every 100

$\mathrm{km}$ distance between the company headquarters and the nearest major city. Furthermore, if the announcement is made in the clean environment, the market reaction will be 79 basis points for every $100 \mathrm{~km}$ distance. This result also demonstrates that the level of asymmetric information contributes negatively to market reaction when companies announce forced turnovers.

\subsection{Alternative return model}

One may argue that all our results are based on abnormal returns calculated based on the Fama-French three-factor model, and that the results may not hold under other models. In order to test the robustness of our results, we use the Carhart four-factor model as an alternative basic return model with which to calculate abnormal returns:

$$
R_{i, t}=R_{f}+\beta_{1} *\left(R_{m}-R_{f}\right)+\beta_{2} * S M B+\beta_{3} * H M L+\beta_{3} * U M D+\varepsilon,
$$

where $U M D$ is a momentum factor. 
Using CARs calculated from this four-factor model as the dependent variable, we replicate all our works in Sections 4.3 and 4.4. The results are reported in Tables B3, B4 and B5 in the Appendix B. We find that the results based on the Carhart four-factor model are qualitatively the same as our main results stated in Sections 4.3 and 4.4. This alternative return model further demonstrates that our results are robust.

\section{Conclusion}

In this paper, we study how markets react to CEO turnover announcements. We find that the level of asymmetric information and the information content in turnover announcements are important factors that can affect the market reaction.

To the best of our knowledge, we are the first to reconcile the two main conflicting theories in literature related to market reactions to top-management turnover. We find that these theories are not competing but rather complement each other. The key variable we add to the analysis is the information frictions between a company and its investors. We argue that when a company has a high level of asymmetric information, the over-assessed-ability hypothesis dominates and the market reacts negatively to a forced turnover announcement. If the company has a low level of asymmetric information, the improved-management hypothesis dominates and the market reacts positively to a forced turnover announcement. When the turnover is voluntary, the market reaction is unrelated to the level of asymmetric information because the announcement reveals little new information to the market.

Our first contribution in this paper is that we fill the gap in the literature by offering an information-based theory about market reaction to CEO turnover announcements. Specifically, we study a hand-collected sample of 750 CEO turnover events between 2004 and 2014 by the type of turnover (forced vs. voluntary) and the announcement environment (general vs. clean). We use different proxies for asymmetric information: (i) analyst coverage, (ii) size, (iii) mean/median analyst forecasting error, (iv) analyst forecasting dispersion, (v) SEP 500 Index code, and (vi) distance between the firm headquarters and the nearest major U.S. city. When a company announces a voluntary CEO turnover, the market reaction is negligible. When a company announces a forced turnover, however, the market reaction is highly related to the level of asymmetric information between the company and its investors. When the level of information asymmetry between a company and its investors is high, the investors are less likely to realize the under-performance of the CEO, and thus the market reaction to a turnover announcement will tend to be negative due to over-assessment of management ability. By contrast, if the level of asymmetric information between a company and its investors is low, the replacement of a poorly performing CEO tends to lead to a positive market reaction due to the potential improvement in management. We use voluntary turnovers as a falsification test and find the market response is not affected by the level of asymmetric information when investors can learn little from the turnover announcement.

We also provide novel empirical evidence suggesting that companies with high levels of asymmetric 
information (with low analyst coverage) tend to embellish the turnover details when they have to announce a forced CEO turnover. We find that such "embellishing" behavior contributes positively to the market reaction when the company is covered by fewer than 10 analysts- companies with higher levels of asymmetric information benefit from embellishing the "forced" aspect of a CEO turnover. This finding implies that investors should be suspicious of seemingly voluntary CEO turnover announcements from firms with low analyst coverage. 


\section{References}

AdAms, J., AND S. MANSI (2009): "CEO turnover and bondholder wealth," Journal of Banking $\&$ Finance, 33, 522-533.

BAJo, E. (2010): "The Information Content of Abnormal Trading Volume," Journal of Business Finance \& Accounting, 37, 950-978.

Ballinger, G., And J. MArcel (2010): "The use of an interim CEO during succession episodes and firm performance," Strategic Management Journal, 31, 262-283.

Barana, L. C., And T. H. D. KIng (2014): "S\&P 500 Index reconstitutions and information asymmetry," Applied Financial Economics, 24, 777-791.

Barth, M. E., And A. P. Hutton (2004): "Analyst earnings forecast revisions and the pricing of accruals," Review of Accounting Studies, 9, 59-96.

Bebchuk, L. A., C. A., And A. Ferrell (2009): "What matters in corporate governance?," Review of Financial Studies, 22, 783-827.

Brennan, M., and A. Subrahmanyam (1995): "Investment analysis and price formation in securities markets," Journal of Financial Economics, 38, 361-381.

Coval, J., And T. Moskowitz (1999): "Home bias at home: local equity preference in domestic portfolios," Journal of Finance, 54, 2045-2073.

Cremers, M., And V. Nair (2005): "Governance mechanisms and equity prices," Journal of Finance, 60, 2859-2894.

Cziraki, P., J. Mondria, and T. Wu (2017): "Asymmetric Attention and Stock Returns," Working papar.

Dedman, E., And S.-J. Lin (2002): "Shareholder wealth effects of CEO departures: Evidence from the UK," Journal of Corporate Finance, 8, 81-104.

Dikolli, S., J. MaYew, and D. NANDA (2014): "CEO tenure and the performance-turnover relation," Review of Accounting Study, 19, 281-327.

Drake, M., D. Roulstone, and J. Thornock (2012): "Investor information demand: evidence from Google searches around earnings announcements," Journal of Accounting Research, 50, 1001-1040.

Ertugrul, M., and K. Krishnan (2011): "Can CEO dismissals be proactive?," Journal of Corporate Finance, 17, 134-151. 
Huson, M., P. Malatesta, and R. Parrino (2004): "Managerial succession and firm performance," Journal of Financial Economics, 74, 237-275.

Intintoli, V., A. Zhang, And W. DAvidson (2014): "The impact of CEO turnover on firm performance around interim successions," Journal of Management $\&$ Governance, 18, 541-587.

IRvine, P. J. (2003): "The incremental impact of analyst initiation of coverage," Journal of Corporate Finance, 9, 431-451.

Ivkovic, Z., And S. Weisbenner (2005): "Local Does As Local Is: Information Content of the Geography of Individual Investors' Common Stock Investments," Journal of Finance, 60, 267-306.

Jarrel, G., And A. Poulsen (1989): "Stock Trading before the Announcement of Tender Offers, Insider Trading or Market Anticipation?," Journal of Law and Organization, 5, 225-248.

Kaplan, S., And B. Minton (2012): "How has CEO turnover changed?," International Review Finance, 12, 57-87.

Khanna, N., And A. Poulsen (1995): "Managers of financially distressed firms: villains or scapegoats?," Journal of Finance, 50, 919-940.

KIRK, M. (2011): "Research for sale: Determinants and consequences of paid-for analyst research," Journal of Financial Economics, 100, 182-200.

Krishnaswami, S., and V. Subramaniam (1999): "Information asymmetry, valuation, and the corporate spin-off decision," Journal of Financial Economics, 53, 73-112.

PARRINO, R. (1997): "CEO turnover and outside succession: A cross-sectional analysis," Journal of Financial Economics, 46(2), 165-197.

Thomas, S. (2002): "Firm diversification and asymmetric information: evidence from analystsâ forecasts and earnings announcements.," Journal of Financial Economics, 64, 373-396.

WARner, J., R. WATts, And K. Wruck (1988): "Stock prices and top management changes," Journal of Financial Economics, 20, 461-492. 


\section{Appendix}

Figure 1: CARs For DifFEREnt types of TURNover (GENERAL ENVIRONMENT)

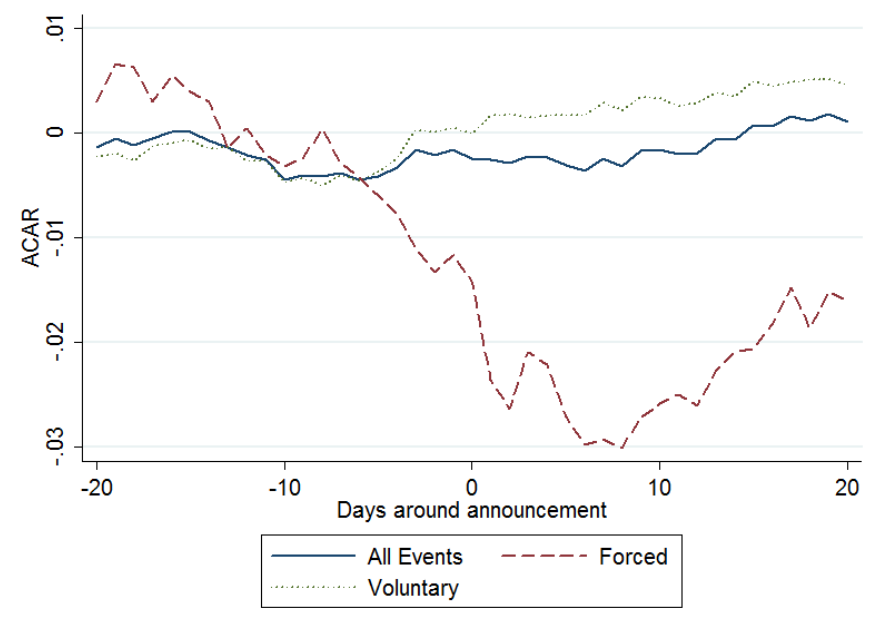

Note: This figure shows the trend of daily abnormal returns around the CEO turnover announcement date in the general environment. (General environment indicates the whole sample.)

Figure 2: CARs FOR DIFFERENT TYPES OF TURNOVER (CLEAN ENVIRONMENT)

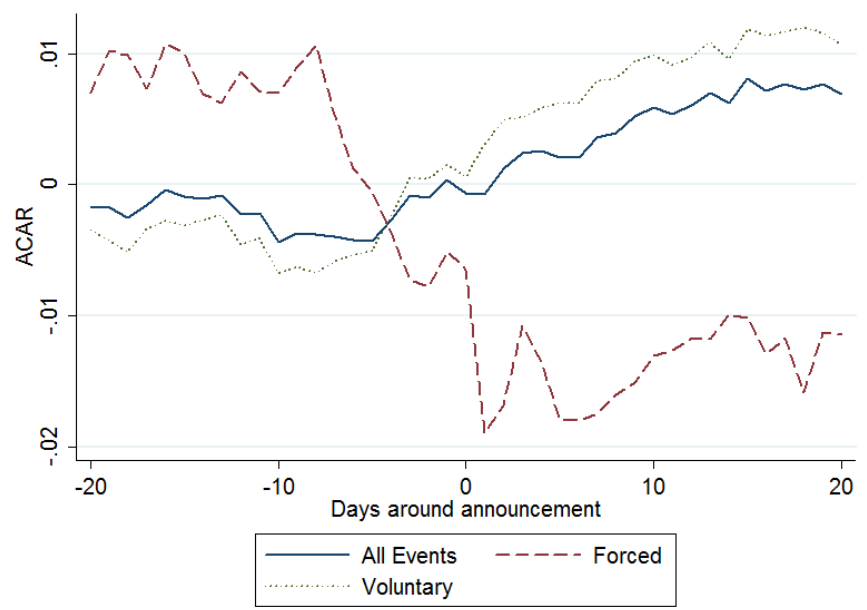

Note: This figure shows the trend of daily abnormal returns around the CEO turnover announcement date in the clean environment. (Clean environment indicates the sub-sample of CEO turnover announcements with no other announcements unrelated to the turnover event during the announcement period. 


\section{FiguRE 3: CARS FOR FORCED TURNOVERS BASED ON DIFFERENT LEVELS OF ANALYST COVERAGE (GENERAL ENVIRONMENT)}

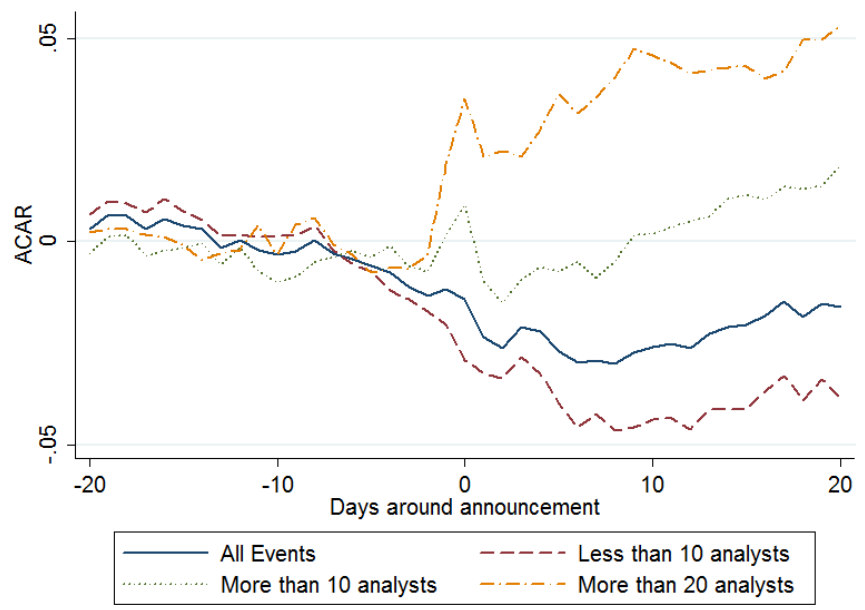

Note: This figure shows the trends of daily abnormal returns around the CEO turnover announcement date in the general environment for forced turnovers. (General environment indicates the whole sample.)

\section{Figure 4: CARs FOR FORCED TURNOVERS BASED ON DIFFERENT LEVELS OF ANALYST COVERAGE (CLEAN ENVIRONMENT)}

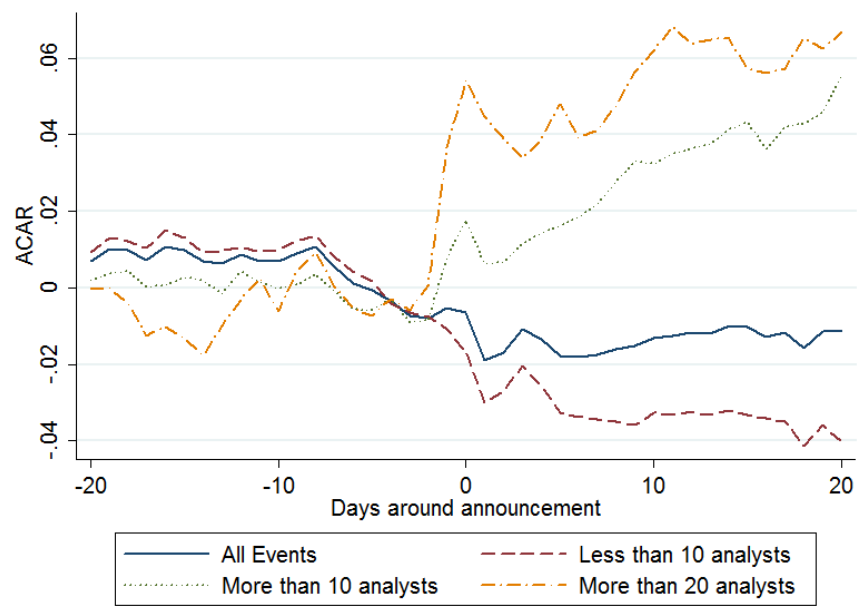

Note: This figure shows the trends of daily abnormal returns around the CEO turnover announcement date in the clean environment for forced turnovers. (Clean environment indicates the sub-sample of CEO turnover announcements with no other announcements unrelated to the turnover event during the announcement period.) 


\section{Figure 5: CARs and analyst coverage (Forced And General)}

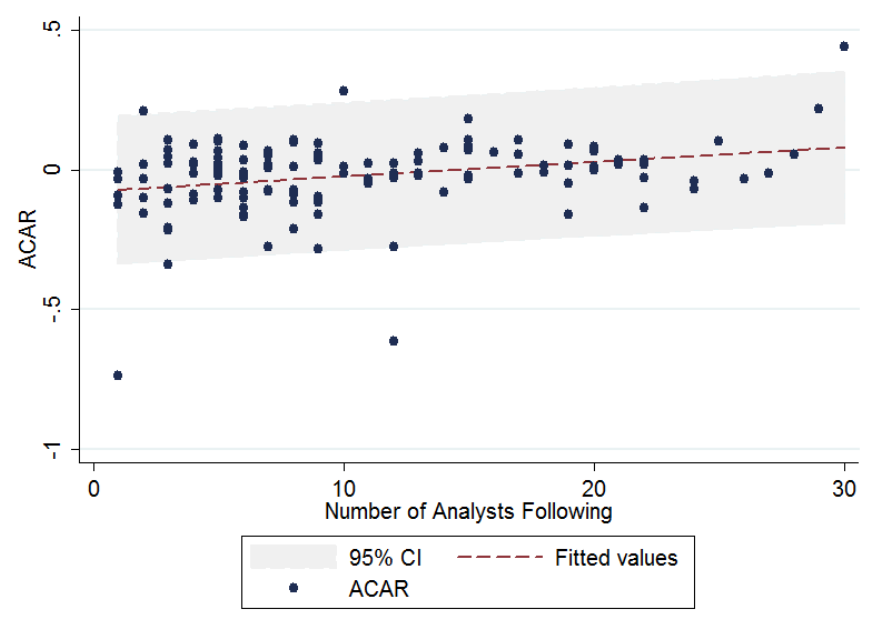

Note: This figure shows the relationship between the market reaction (measured by CAR from week -1 to week +1 around the turnover announcement) and the number of analysts following the company in the general environment for forced turnovers. (General environment indicates the whole sample.)

Figure 6: CARs AND ANALYst COVERAge (FORCED AND ClEAN)

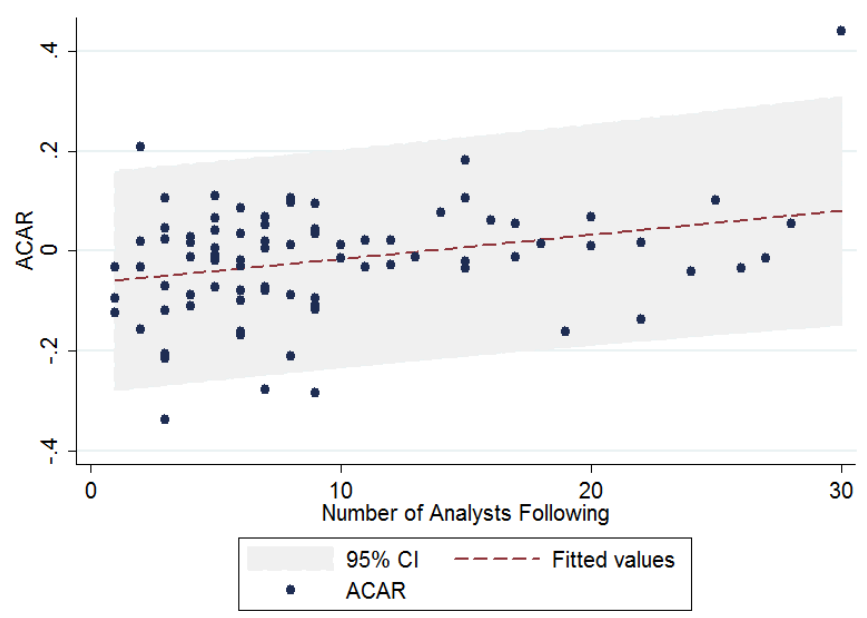

Note: This figure shows the relationship between the market reaction (measured by CAR from week -1 to week +1 around the turnover announcement) and the number of analysts following the company in the clean environment for forced turnovers. (Clean environment indicates the sub-sample of CEO turnover announcements with no other announcements unrelated to the turnover event during the announcement period.) 
Figure 7: Market REACtion ANd Embellishing BehaVior (GEnERAl ENVironment)

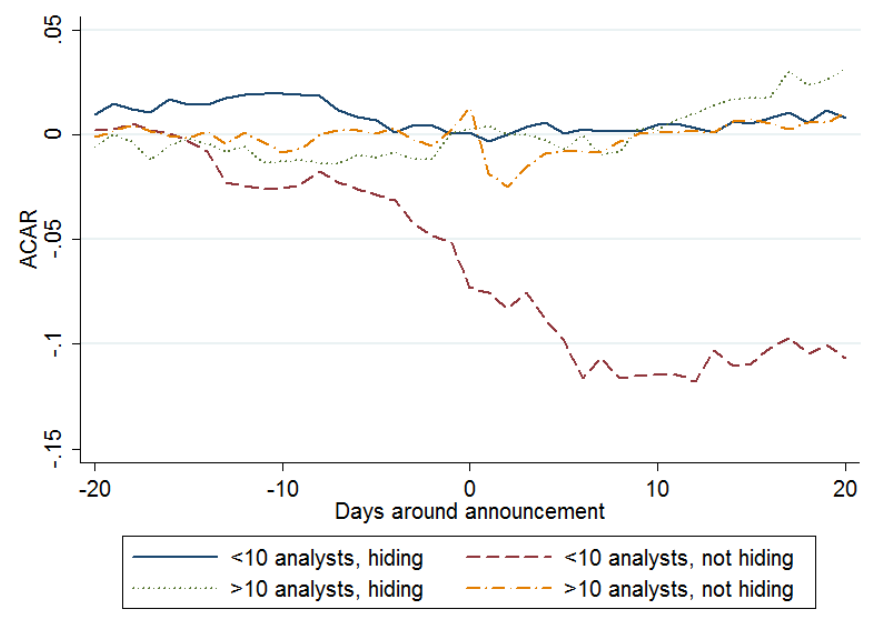

Note This figure shows the effect of embellishing behavior on market reaction for different levels of firm analyst coverage in the general environment. (General environment indicates the whole sample.)

Figure 8: Market ReACtion And EMbellishing BehaVior (ClEAN ENVironment)

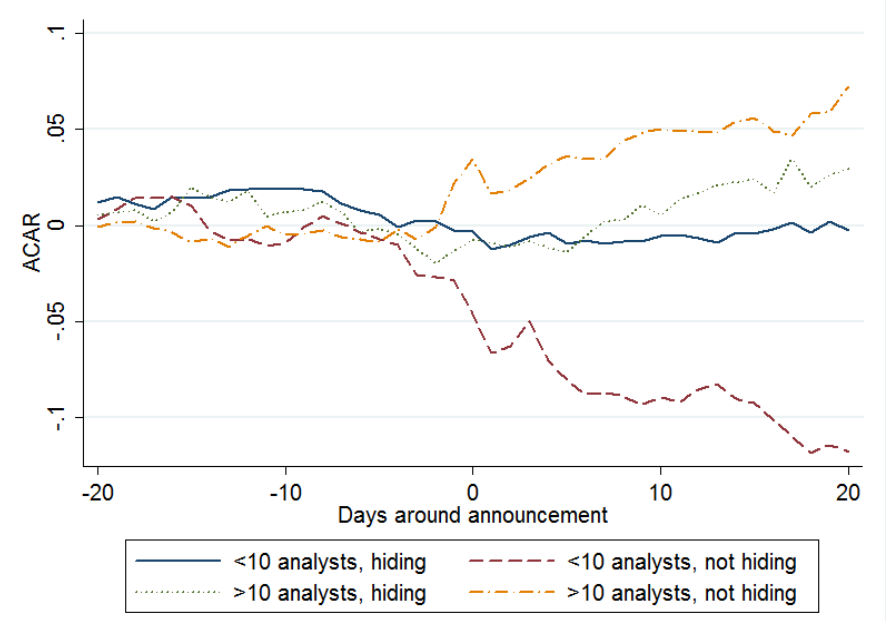

Note: This figure shows the effect of embellishing behavior on market reaction for different levels of firm analysts coverage in the clean environment. (Clean environment indicates the sub-sample of CEO turnover announcements with no other announcements unrelated to the turnover event during the announcement period.) 
TABle 1: Summary STATistics of SEleCted VARIABles in SUB-SAMPles With Different LEVELS OF ANALYST COVERAGE

\begin{tabular}{lccccc}
\hline \hline & & \multicolumn{2}{c}{ Panel A: General Environment } & & \\
& Full sample & Analysts $<=10$ & $10<$ Analysts $<=20$ & Analysts $>10$ & Analysts $>20$ \\
\hline Observations & 750 & 424 & 238 & 326 & 88 \\
Inst Ownership & 0.7685 & 0.7554 & 0.7974 & 0.7857 & 0.7538 \\
Size (Market Cap) & 7.8986 & 7.0896 & 8.6230 & 8.9508 & 9.8373 \\
B/M Ratio & 0.5611 & 0.6142 & 0.5122 & 0.4920 & 0.4371 \\
Distance & 200.74 & 219.26 & 190.16 & 175.91 & 137.50 \\
Analyst Coverage & 2.2481 & 1.7431 & 2.7665 & 2.9050 & 3.2797 \\
SP (percentage) & $287(38.3 \%)$ & $70(16.5 \%)$ & $138(58.0 \%)$ & $217(66.6 \%)$ & $79(89.8 \%)$ \\
MD (percentage) & $207(27.6 \%)$ & $131(30.9 \%)$ & $67(28.1 \%)$ & $76(23.3 \%)$ & $9(10.2 \%)$ \\
SM (percentage) & $256(34.1 \%)$ & $223(52.6 \%)$ & $33(13.8 \%)$ & $33(10.1 \%)$ & $0(0 \%)$ \\
\hline & & Panel B: Clean Environment & & 174 \\
& Full sample & Analysts $<10$ & $10<$ Analysts<=20 & Analysts $>10$ & Analysts>20 \\
\hline Observations & 484 & 310 & 132 & 0.8023 & 42 \\
InstOwnership & 0.7715 & 0.7543 & 0.8023 & 8.6081 & 0.8023 \\
Size (Market Cap) & 7.5934 & 7.0239 & 8.2937 & 0.5065 & 9.5960 \\
B/M Ratio & 0.5835 & 0.6269 & 0.5211 & 168.46 & 0.4605 \\
Distance & 198.17 & 214.42 & 178.17 & 2.8708 & 137.37 \\
Analyst Coverage & 2.1570 & 1.7563 & 2.7370 & $101(58.0 \%)$ & 3.2913 \\
SP (percentage) & $148(30.6 \%)$ & $47(15.2 \%)$ & $64(48.5 \%)$ & $50(28.7 \%)$ & $5(11.9 \%)$ \\
MD (percentage) & $142(29.3 \%)$ & $92(29.7 \%)$ & $45(34.1 \%)$ & $23(13.2 \%)$ & $0(0 \%)$ \\
SM (percentage) & $194(40.1 \%)$ & $171(55.2 \%)$ & $23(17.4 \%)$ & & \\
\hline
\end{tabular}

Note: This table reports the mean value for variables of interest in different quantiles of analysts coverage. Panel A reports results in the general environment. Panel B reports results in the clean environment. Analysts is the number of analysts following the company; InstOwnership is the percentage of shares owned by institutional investors; Size is the market capitalization; B/M Ratio is the ratio of the company's book value to market capitalization; Dist is the minimum distance between the company's headquarters and the 21 most populous cities in U.S.; analyst coverage is calculated as the natural log of $(1+$ Analysts $)$; SP measures the number and proportion of the turnover events where the announcing company is listed in the S\&P 500 Index; MD measures the number and proportion of turnover events where the announcing company is listed in the S\&P MidCap 400 Index; SM measures the number and proportion of turnover events where the announcing company is listed in the S\&P SmallCap 600 Index.

TABle 2: Main Hypotheses

\begin{tabular}{lcc}
\hline \hline & High Information Asymmetry Firms & Low Information Asymmetry Firms \\
\hline Forced Turnover & Bad news to investors & Good news to investors \\
& (Over-assessed Ability Hypothesis) & (Improved Management Hypothesis) \\
Voluntary Turnover & Weakly good news/no news & Weakly good news/no news \\
\hline
\end{tabular}

Note: This table summarize the main hypotheses of the paper. When CEO turnover is forced, market reaction is based on the level of asymmetric information between the announcing firm and its investors. If the level of asymmetric information is high, the over-assessed-ability hypothesis dominates and the market reacts negatively. If the level of asymmetric information is low, the improved-management hypothesis dominates and the market reacts positively. When the CEO turnover is voluntary, the market reaction is statistically insignificant or weakly positive, and it is unaffected by the level of asymmetric information. 
Table 3: Cumulative abnormal Returns for an Event Window days $[-1,+1]$ ARound CEO TURNOVER ANNOUNCEMENTS

\begin{tabular}{|c|c|c|c|c|}
\hline \multicolumn{5}{|c|}{ Panel A: General Environment } \\
\hline Turnover Type & General & Analysts $<=10$ & Analysts $>10$ & Analysts $>20$ \\
\hline \multirow[t]{2}{*}{ All Turnovers } & -0.0004 & -0.0010 & 0.0004 & $0.0133^{* *}$ \\
\hline & $(0.0022)$ & $(0.0029)$ & $(0.0035)$ & $(0.0052)$ \\
\hline \multirow[t]{2}{*}{ Forced } & -0.0103 & -0.0155 & -0.0023 & 0.0241 \\
\hline & $(0.0087)$ & $(0.0107)$ & $(0.0149)$ & $(0.0176)$ \\
\hline \multirow[t]{2}{*}{ Voluntary } & 0.0016 & 0.0022 & 0.0008 & $0.0112^{* *}$ \\
\hline & $(0.0020)$ & $(0.0027)$ & $(0.0031)$ & $(0.0052)$ \\
\hline \multirow[t]{2}{*}{ External } & -0.0002 & -0.0045 & 0.0092 & $0.0305^{*}$ \\
\hline & $(0.0050)$ & $(0.0065)$ & $(0.0070)$ & $(0.0151)$ \\
\hline \multirow[t]{2}{*}{ Internal } & -0.0004 & 0.0004 & -0.0013 & $0.0094^{*}$ \\
\hline & $(0.0025)$ & $(0.0032)$ & $(0.0039)$ & $(0.0053)$ \\
\hline \multirow[t]{2}{*}{ Forced \& External } & -0.0140 & -0.0250 & 0.0087 & 0.0531 \\
\hline & $(0.0136)$ & $(0.0181)$ & $(0.0176)$ & $(0.0316)$ \\
\hline \multirow[t]{2}{*}{ Forced \& Internal } & -0.0083 & -0.0096 & -0.0066 & 0.0081 \\
\hline & $(0.0113)$ & $(0.0133)$ & $(0.0198)$ & $(0.0205)$ \\
\hline \multirow[t]{2}{*}{ Voluntary \& External } & 0.0046 & 0.0024 & 0.0094 & 0.0202 \\
\hline & $(0.0047)$ & $(0.0061)$ & $(0.0072)$ & $(0.0167)$ \\
\hline \multirow[t]{2}{*}{ Voluntary \& Internal } & 0.0008 & 0.0021 & -0.0006 & $0.0096^{*}$ \\
\hline & $(0.0023)$ & $(0.0030)$ & $(0.0035)$ & $(0.0054)$ \\
\hline \multicolumn{5}{|c|}{ Panel B: Clean Environment } \\
\hline Turnover Type & General & Analysts $<=10$ & Analysts $>10$ & Analysts $>20$ \\
\hline \multirow[t]{2}{*}{ All Turnovers } & 0.0002 & -0.0027 & $0.0055^{*}$ & 0.0100 \\
\hline & $(0.0024)$ & $(0.0033)$ & $(0.0031)$ & $(0.0064)$ \\
\hline \multirow[t]{2}{*}{ Forced } & -0.0112 & $-0.0022^{*}$ & 0.0148 & $0.0440^{*}$ \\
\hline & $(0.0098)$ & $(0.0128)$ & $(0.0115)$ & $(0.0189)$ \\
\hline \multirow{2}{*}{ Voluntary } & 0.0026 & 0.0018 & 0.0039 & 0.0019 \\
\hline & $(0.0020$ & $(0.0027)$ & $(0.0030)$ & $(0.0059)$ \\
\hline \multirow[t]{2}{*}{ External } & -0.0026 & -0.0058 & 0.0058 & 0.0268 \\
\hline & $(0.0057)$ & $(0.0073)$ & $(0.0078)$ & $(0.0154)$ \\
\hline \multirow[t]{2}{*}{ Internal } & 0.0013 & -0.0013 & 0.0054 & 0.0032 \\
\hline & $(0.0025)$ & $(0.0034)$ & $(0.0033)$ & $(0.0062)$ \\
\hline \multirow[t]{2}{*}{ Forced \& External } & -0.0148 & -0.0261 & 0.0139 & 0.0709 \\
\hline & $(0.0176)$ & $(0.0221)$ & $(0.0262)$ & $(0.0338)$ \\
\hline \multirow[t]{2}{*}{ Forced \& Internal } & -0.0089 & -0.0200 & 0.0153 & $0.0172^{*}$ \\
\hline & $(0.0116)$ & $(0.0158)$ & $(0.0112)$ & $(0.0068)$ \\
\hline \multirow{2}{*}{ Voluntary \& External } & 0.0014 & 0.0006 & 0.0032 & 0.0047 \\
\hline & $(0.0050)$ & $(0.0065)$ & $(0.0065)$ & $(0.0104)$ \\
\hline \multirow[t]{2}{*}{ Voluntary \& Internal } & 0.0030 & 0.0023 & 0.0041 & 0.0011 \\
\hline & $(0.0021)$ & $(0.0027)$ & $(0.0034)$ & $(0.0071)$ \\
\hline
\end{tabular}

Note: This table summarizes market reaction to turnover events from day -1 to day +1 around the announcement date. Results are reported for different sub-samples based on the number of analysts following the company. Panel A reports results in the general environment. Panel B reports results in the clean environment. Analysts is the number of analysts following the company. * ,** and *** denote significance at the $10 \%, 5 \%$ and $1 \%$ level, respectively. Standard errors are in brackets. 
Table 4: Abnormal Trading Volume (Daily)

\begin{tabular}{|c|c|c|c|c|}
\hline day & General & Clean & Forced (General) & Forced (Clean) \\
\hline \multirow[t]{2}{*}{-7} & 0.0084 & 0.0495 & $-0.1935^{* *}$ & -0.1361 \\
\hline & $(0.0377)$ & $(0.0472)$ & $(0.0816)$ & $(0.0993)$ \\
\hline \multirow[t]{2}{*}{-6} & -0.0264 & -0.0038 & $-0.2376^{* * *}$ & $-0.2245^{* *}$ \\
\hline & $(0.0396)$ & $(0.0518)$ & $(0.0809)$ & $(0.1000)$ \\
\hline \multirow[t]{2}{*}{-5} & 0.0015 & 0.0221 & $-0.2329 * *$ & -0.1786 \\
\hline & $(0.0377)$ & $(0.0481)$ & $(0.0959)$ & $(0.1326)$ \\
\hline \multirow[t]{2}{*}{-4} & $0.0774^{* *}$ & 0.0764 & -0.0891 & -0.1145 \\
\hline & $(0.0385)$ & $(0.0472)$ & $(0.0898)$ & $(0.1131)$ \\
\hline \multirow[t]{2}{*}{-3} & 0.0214 & 0.0641 & -0.0759 & -0.0209 \\
\hline & $(0.0340)$ & $(0.0432)$ & $(0.0771)$ & $(0.1011)$ \\
\hline \multirow[t]{2}{*}{-2} & 0.0240 & 0.0306 & 0.0299 & 0.0318 \\
\hline & $(0.0371)$ & $(0.0450)$ & $(0.0882)$ & $(0.1079)$ \\
\hline \multirow[t]{2}{*}{-1} & $0.0922^{* *}$ & $0.0806^{*}$ & 0.0889 & 0.1257 \\
\hline & $(0.0363)$ & $(0.0467)$ & $(0.0961)$ & $(0.1199)$ \\
\hline \multirow[t]{2}{*}{0} & $0.5106^{* * * *}$ & $0.3201^{* * * *}$ & $0.8128^{* * * *}$ & $0.6831^{* * * *}$ \\
\hline & $(0.0455)$ & $(0.0503)$ & $(0.1300)$ & $(0.1559)$ \\
\hline \multirow[t]{2}{*}{1} & $0.6334^{* * * *}$ & $0.4525^{* * * *}$ & $1.2691^{* * * *}$ & $1.0181 * * * *$ \\
\hline & $(0.0464)$ & $(0.0531)$ & $(0.1335)$ & $(0.1550)$ \\
\hline \multirow[t]{2}{*}{2} & $0.3007^{* * * *}$ & $0.1947^{* * * *}$ & $0.5381^{* * * *}$ & $0.4025^{* * *}$ \\
\hline & $(0.0388)$ & $(0.0491)$ & $(0.1001)$ & $(0.1208)$ \\
\hline \multirow[t]{2}{*}{3} & $0.1792^{* * * *}$ & $0.1479^{* * *}$ & $0.2587^{* * *}$ & 0.2443 \\
\hline & $(0.0390)$ & $(0.0490)$ & $(0.0905)$ & $(0.1062)$ \\
\hline \multirow[t]{2}{*}{4} & $0.1724^{* * * *}$ & $0.1467^{* * *}$ & $0.2268^{* *}$ & 0.1646 \\
\hline & $(0.0375)$ & $(0.0462)$ & $(0.0941)$ & (0.1119) \\
\hline \multirow[t]{2}{*}{5} & $0.0872^{* *}$ & 0.0734 & 0.1295 & 0.1309 \\
\hline & $(0.0389)$ & $(0.0495)$ & $(0.0997)$ & $(0.1358)$ \\
\hline \multirow[t]{2}{*}{6} & 0.0414 & 0.0443 & 0.1358 & 0.0813 \\
\hline & $(0.0363)$ & $(0.0450)$ & $(0.0937)$ & $(0.1123)$ \\
\hline \multirow[t]{2}{*}{7} & $0.1150^{* * *}$ & $0.1343^{* * *}$ & $0.2197^{* *}$ & 0.1125 \\
\hline & $(0.0378)$ & $(0.0469)$ & $(0.0983)$ & $(0.1122)$ \\
\hline \multirow[t]{2}{*}{8} & $0.1251^{* * * *}$ & $0.1122^{* *}$ & 0.0884 & 0.0352 \\
\hline & $(0.0375)$ & $(0.0462)$ & $(0.0867)$ & $(0.1022)$ \\
\hline \multirow[t]{2}{*}{9} & $0.0744^{* *}$ & $0.0801^{*}$ & 0.0918 & 0.0418 \\
\hline & $(0.0355)$ & $(0.0426)$ & $(0.0819)$ & $(0.1010)$ \\
\hline \multirow[t]{2}{*}{10} & 0.0310 & 0.0752 & -0.0474 & -0.0389 \\
\hline & $(0.0378)$ & $(0.0458)$ & $(0.0850)$ & (0.1037) \\
\hline
\end{tabular}

Note: This table reports the daily normalized abnormal trading volume. $N A V_{i t}=\frac{T V_{i t}-\mu_{i t}}{\sigma_{i t}}$, and $\mu_{i t}=\frac{1}{66} \sum_{t=1}^{66} T V_{i t}$, where $T V_{i t}$ is the trading volume for stock $i$ on day $t$ (computed as the natural log of $1+$ the trading volume), $\mu_{i t}$ and $\sigma_{i t}$ are the mean and standard deviation of trading volume during the 66-day window immediately prior to the observation. Day 0 is the announcement date. General indicates the total sample; Clean indicates the sub-sample with clean announcement; Forced (General) indicates the sub-sample that consists only of forced turnovers; Forced (Clean) indicates the sub-sample that consists only of forced turnovers with clean announcement. ${ }^{*},{ }^{* *}$ and $* * *$ denote significance at the $10 \%, 5 \%$ and $1 \%$ level, respectively. Standard errors are in brackets. 
Table 5: Abnormal Trading Volume (Weekly)

\begin{tabular}{ccccc}
\hline \hline week & General & Clean & Forced (General) & Forced (Clean) \\
\hline-3 & 0.0150 & 0.0262 & 0.0037 & 0.1119 \\
& $(0.0272)$ & $(0.0346)$ & $(0.0717)$ & $(0.0874)$ \\
-2 & 0.0382 & 0.0654 & -0.1384 & -0.1039 \\
& $(0.0278)$ & $(0.0353)$ & $(0.0690)$ & $(0.0866)$ \\
-1 & 0.0165 & 0.0489 & -0.1081 & -0.0516 \\
& $(0.0265)$ & $(0.0337)$ & $(0.0633)$ & $(0.0854)$ \\
\hline 0 & $0.3018^{* * * *}$ & $0.2207^{* * * *}$ & $0.5235^{* * * *}$ & $0.3874^{* * * *}$ \\
& $(0.0285)$ & $(0.0345)$ & $(0.0769)$ & $0.0882)$ \\
1 & $0.1464^{* * * *}$ & $0.1283^{* * * *}$ & $0.2541^{* * * *}$ & $0.0909)$ \\
& $(0.0279)$ & $(0.0344)$ & $(0.0721)$ & 0.0218 \\
2 & 0.0187 & 0.0433 & 0.0197 & $(0.0746)$ \\
& $(0.0267)$ & $(0.0327)$ & $(0.0630)$ & 0.0238 \\
3 & -0.0166 & 0.0154 & -0.0199 & $(0.0764)$ \\
& $(0.0265)$ & $(0.0323)$ & $(0.0651)$ & \\
\hline
\end{tabular}

Note: This table reports the weekly abnormal trading volume. $W A A V_{i, t}=\frac{W A T V_{i, t}-\mu_{i, t}}{\sigma_{i, t}}$, and $\mu_{i, t}=\frac{1}{20} \sum_{t=1}^{20} W A T V_{i, t}$. Week 0 is the announcement week. General indicates the total sample; Clean indicates the sub-sample with "clean" announcement; Forced (General) indicates the subsample that consists only of forced turnovers; Forced (Clean) indicates the sub-sample that consists only of forced turnovers with clean announcement. *, ** and *** denote significance at the $10 \%, 5 \%$ and $1 \%$ level, respectively. Standard errors are in brackets. 
Table 6: Cumulative abnormal Returns for the event window of Weeks $[-1,+1]$ AROUND CEO TURNOVER ANNOUNCEMENTS

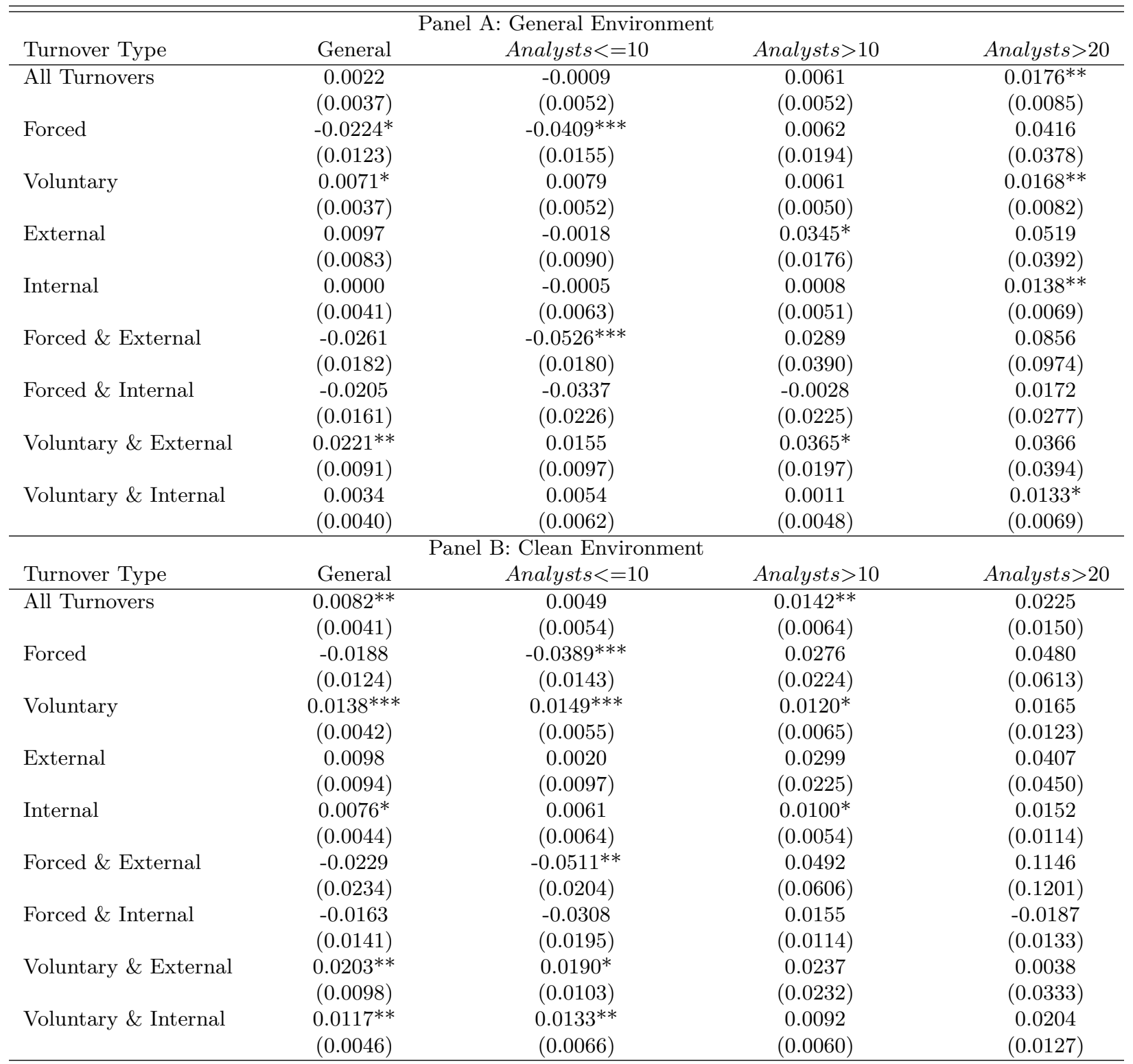

Note: This table summarizes market reaction to turnover events from week -1 to week +1 around the announcement week. Results are reported for different sub-samples based on level of analyst coverage. Panel A reports results in the general environment. Panel B reports results in the clean environment. Analysts is the number of analysts following the company. ${ }^{*}, * *$ and ${ }^{* * *}$ denote significance at the $10 \%, 5 \%$ and $1 \%$ level, respectively. Standard errors are in brackets. 
TABle 7: BASELINE RESUlT

\begin{tabular}{|c|c|c|c|c|}
\hline \multirow[t]{3}{*}{ Dep. Variable: } & \multicolumn{4}{|c|}{ CAR $[\mathrm{w}(-1), \mathrm{w}(+1)]:$ Market reaction in announcement period of week -1 to +1} \\
\hline & $(1)$ & $(2)$ & $(3)$ & $(4)$ \\
\hline & General Environment & Clean Environment & General Environment & Clean Environment \\
\hline \multirow[t]{2}{*}{ Constant } & 0.0339 & 0.0210 & 0.0636 & 0.0673 \\
\hline & $(0.0390)$ & $(0.0317)$ & $(0.0491)$ & $(0.0460)$ \\
\hline \multirow[t]{2}{*}{ Ext } & 0.00115 & -0.00914 & 0.00287 & -0.00348 \\
\hline & $(0.0270)$ & $(0.0308)$ & $(0.0271)$ & $(0.0313)$ \\
\hline \multirow[t]{2}{*}{ Forced } & $-0.139 * * *$ & $-0.136^{* * *}$ & $-0.135^{* * *}$ & $-0.135^{* * *}$ \\
\hline & $(0.0430)$ & $(0.0454)$ & $(0.0425)$ & $(0.0448)$ \\
\hline \multirow[t]{2}{*}{ Anacov } & -0.000629 & -0.00687 & -0.00341 & -0.0108 \\
\hline & $(0.00743)$ & $(0.00809)$ & $(0.00783)$ & $(0.00834)$ \\
\hline \multirow{2}{*}{ Ext*Anacov } & 0.00684 & 0.00716 & 0.00609 & 0.00456 \\
\hline & $(0.0132)$ & $(0.0149)$ & $(0.0131)$ & $(0.0148)$ \\
\hline \multirow[t]{2}{*}{ Forced*Anacov } & $0.0496^{* * *}$ & $0.0482^{* *}$ & $0.0482^{* * *}$ & $0.0486^{* *}$ \\
\hline & $(0.0185)$ & $(0.0209)$ & $(0.0185)$ & $(0.0208)$ \\
\hline \multicolumn{5}{|l|}{ Controls } \\
\hline \multirow[t]{2}{*}{ InstOwnership } & -0.00351 & 0.0112 & -0.0121 & -0.00944 \\
\hline & $(0.0236)$ & $(0.0239)$ & $(0.0252)$ & $(0.0244)$ \\
\hline \multirow[t]{2}{*}{ Size } & -0.00170 & 0.000667 & -0.000686 & 0.00230 \\
\hline & $(0.00443)$ & $(0.00388)$ & $(0.00429)$ & $(0.00392)$ \\
\hline \multirow[t]{2}{*}{ BMratio } & $-0.0243^{* *}$ & $-0.0242^{*}$ & $-0.0239^{*}$ & $-0.0253^{*}$ \\
\hline & $(0.0124)$ & $(0.0146)$ & $(0.0138)$ & $(0.0153)$ \\
\hline \multirow[t]{2}{*}{ Spread } & -0.244 & 0.0110 & -0.308 & -0.128 \\
\hline & $(0.291)$ & $(0.300)$ & $(0.299)$ & $(0.268)$ \\
\hline \multirow[t]{2}{*}{ Turnover } & 0.00477 & 0.00289 & 0.00520 & 0.00370 \\
\hline & $(0.00700)$ & $(0.00676)$ & $(0.00722)$ & $(0.00664)$ \\
\hline Year FE & No & No & Yes & Yes \\
\hline Industry FE & No & No & Yes & Yes \\
\hline Observations & 750 & 484 & 750 & 484 \\
\hline R-Squared & 0.065 & 0.061 & 0.082 & 0.100 \\
\hline
\end{tabular}

Note: This table reports our baseline results. Columns 1 and 3 report the results in the general environment. Columns 2 and 4 report the results in the clean environment. Columns 1 and 2 do not control for fixed effects. Columns 3 and 4 control for year and industry fixed effects. Industries are classified based on the Fama-French 12 industry classification method. The model is as follows: $C A R_{i}[w(-1), w(+1)]=\alpha+\beta_{e}$ Ext $_{i}+\beta_{f}$ Forced $_{i}+\beta_{a}$ Anacov $_{i}+\beta_{a e}$ Anacov $_{i} *$ Ext $_{i}+\beta_{\text {af }}$ Anacov $_{i} *$ Forced $_{i}+\beta_{6}$ InstOwnership $_{i}+\beta_{7}$ Size $_{i}+\beta_{8}$ BMratio $_{i}+\beta_{9}$ Spread $_{i}+\beta_{10}$ Turnover $_{i}+\epsilon_{i}$. The dependent variable is CAR spanning week -1 to week +1 , calculated based on the Fama-French three-factor model. $E x t=\{0,1\}$ measures whether a turnover event $i$ is an external replacement or not; Forced $=\{0,1\}$ measures whether turnover event $i$ is a forced turnover; Anacov $=\ln (1+$ AnalystFollowing $)$ measures analyst coverage for the company announcing turnover event $i$, as a proxy for the level of asymmetric information between the company and investors; \{InstOwnership, Size, BMratio, Spread and Turnover $\}$ are control variables that measure the characteristics of the company involved in turnover event $i$; InstOwnership is the proportion of shares owned by institutional investors; Size is the market capitalization of the company; BMrario is the ratio of the company's book value to market capitalization; Spread is the high-low price measure for the bid-ask spread; Turnover $=$ trading volume / total shares outstanding, which measures the stock turnover rate. ${ }^{*}, * *$ and $* * *$ denote significance at the $10 \%, 5 \%$ and $1 \%$ level, respectively. Robust standard errors are in brackets. 
TABle 8: CorRelation BetWeEn PROXIES FOR ASYMmetric INFORMATION

\begin{tabular}{lcccccc}
\hline \hline & Anacov & Size & Error $_{\text {Mean }}$ & Error $_{\text {Med }}$ & Dispersion & S\&P \\
\hline Anacov & 1.0000 & & & & & \\
Size & 0.6549 & 1.0000 & & & & \\
Error $_{\text {Mean }}$ & -0.0693 & -0.0968 & 1.0000 & & & \\
Error $_{\text {Med }}$ & -0.0699 & -0.0969 & 0.9995 & 1.0000 & & \\
Dispersion & -0.0089 & -0.0577 & 0.8586 & 0.8529 & 1.0000 & 1.0000 \\
S\&P & 0.5139 & 0.7629 & -0.0537 & -0.0538 & -0.0207 & -0.1229 \\
Dist & -0.0501 & -0.0875 & 0.2348 & 0.2358 & 0.2308 & 1.0000 \\
\hline
\end{tabular}

Note: This table summarizes the correlation between the different proxies for the level of asymmetric information between a firm and its investors. Anacov is the analyst coverage; Size is firm market capitalization; Error ${ }_{M e a n}$ is

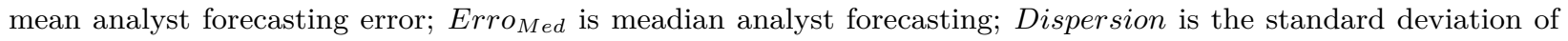
analyst forecasts, and it measures analyst forecasting dispersion; $S \& P$ indicates whether the announcing company is listed in the S\&P 500 Index; Dist is the shortest distance between the company's headquarters and the 21 most populous cities in the U.S. 
Table 9: Alternative Proxies - General Environment

\begin{tabular}{|c|c|c|c|c|c|c|}
\hline \multirow[t]{2}{*}{ Dep. Variable } & \multicolumn{6}{|c|}{ 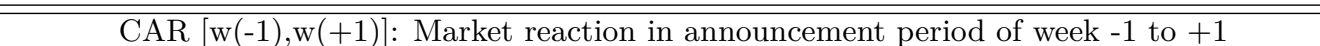 } \\
\hline & (1) & $(2)$ & $(3)$ & $(4)$ & $(5)$ & $(6)$ \\
\hline Proxy: & Size & Error $_{\text {Mean }}$ & Error $_{M e d}$ & Dispersion & $S \& P$ & Dist \\
\hline \multirow[t]{2}{*}{ Constant } & $0.0727^{*}$ & -0.0045 & -0.0043 & $-0.0641^{* *}$ & -0.0011 & -0.0146 \\
\hline & $(0.4299)$ & $(0.0438)$ & $(0.0438)$ & $(0.0327)$ & $(0.0418)$ & $(0.0440)$ \\
\hline \multirow[t]{2}{*}{ Ext } & $-0.1049^{* *}$ & $0.0202^{* *}$ & $0.0203^{* *}$ & 0.0158 & 0.0015 & $0.0201^{*}$ \\
\hline & $(0.0512)$ & $(0.0101)$ & $(0.0103)$ & $(0.0104)$ & $(0.0106)$ & $(0.0121)$ \\
\hline \multirow[t]{2}{*}{ Forced } & $-0.2028^{* * *}$ & $-0.0252^{* *}$ & $-0.0257^{* *}$ & $-0.0187^{*}$ & $-0.0500^{* * *}$ & -0.0216 \\
\hline & $(0.5831)$ & $(0.0124)$ & $(0.0124)$ & $(0.0307)$ & $(0.0146)$ & $(0.0147)$ \\
\hline \multirow[t]{2}{*}{ Proxy } & $-0.0089^{*}$ & 0.1835 & 0.1798 & -0.0205 & $-0.0308^{* * *}$ & -0.0000164 \\
\hline & $(0.0051)$ & $(0.1149)$ & $(0.1212)$ & $(0.0167)$ & $(0.0104)$ & $(0.0000128)$ \\
\hline \multirow[t]{2}{*}{ Ext $*$ Proxy } & $0.0162^{* *}$ & $-0.2786^{* *}$ & $-0.2872^{*}$ & 0.0442 & $0.0545^{* *}$ & -0.0000232 \\
\hline & $(0.0068)$ & $(0.1098)$ & $(0.1608)$ & $(0.0307)$ & $(0.0235)$ & $(0.0000274)$ \\
\hline \multirow[t]{2}{*}{ Forced $*$ Proxy } & $0.0224^{* * *}$ & $-0.2041^{*}$ & $-0.2010^{*}$ & -0.0095 & $0.0565^{* *}$ & $-0.0000435^{*}$ \\
\hline & $(0.0069)$ & $(0.1128)$ & $(0.1196)$ & $(0.0172)$ & $(0.0233)$ & $(0.000025)$ \\
\hline \multicolumn{7}{|l|}{ Controls } \\
\hline \multirow[t]{2}{*}{ InstOwnership } & 0.0007 & 0.0009 & 0.0011 & 0.0083 & 0.0048 & 0.0052 \\
\hline & $(0.0237)$ & $(0.0237)$ & $(0.0237)$ & $(0.0239)$ & $(0.0230)$ & $(0.0239)$ \\
\hline \multirow[t]{2}{*}{ Size } & & -0.0003 & -0.0002 & $0.0064^{*}$ & 0.0011 & -0.0014 \\
\hline & & $(0.0052)$ & $(0.0052)$ & $(0.0035)$ & $(0.0050)$ & (0.0049) \\
\hline \multirow[t]{2}{*}{ Anacov } & 0.0115 & 0.0089 & 0.0087 & 0.0014 & 0.0111 & 0.0092 \\
\hline & $(0.0072)$ & $(0.0438)$ & $(0.0082)$ & $(0.0077)$ & $(0.0073)$ & $(0.0072)$ \\
\hline \multirow[t]{2}{*}{ BMratio } & $-0.0243^{*}$ & -0.0138 & -0.0141 & -0.0116 & $-0.0236^{*}$ & -0.0219 \\
\hline & $(0.0143)$ & $(0.0151)$ & $(0.0151)$ & $(0.0134)$ & $(0.0131)$ & (0.0143) \\
\hline \multirow[t]{2}{*}{ Spread } & -0.1834 & -0.0943 & -0.0983 & $0.7750^{* * *}$ & -0.1685 & -0.1772 \\
\hline & $(0.5046)$ & $(0.5841)$ & $(0.5815)$ & $(0.2712)$ & $(0.5104)$ & $(0.5290)$ \\
\hline \multirow[t]{2}{*}{ Turnover } & -0.0022 & -0.0053 & -0.0005 & -0.0040 & -0.0018 & -0.0014 \\
\hline & $(0.0067)$ & $(0.0073)$ & $(0.0073)$ & $(0.0068)$ & $(0.0066)$ & $(0.0071)$ \\
\hline Observations & 750 & 739 & 739 & 707 & 750 & 735 \\
\hline R-Squared & 0.0705 & 0.0416 & 0.0393 & 0.0525 & 0.0642 & 0.0527 \\
\hline
\end{tabular}

Note: This table reports the results from the regression in which We use alternative proxies for information asymmetry in our baseline model in the general environment. The model is as follows: $C_{A} R_{i}[w(-1), w(+1)]=$ $\alpha+\beta_{e}$ Ext $_{i}+\beta_{f}$ Forced $_{i}+\beta_{p}$ Proxy $_{i}+\beta_{\text {pe }}$ Proxy $_{i} *$ Ext $_{i}+\beta_{p f}$ Proxy $_{i} *$ Forced $_{i}+\beta_{6}$ Control $_{i}+\epsilon_{i}$. The dependent variable is CAR from week -1 to week +1 , calculated based on the Fama-French three-factor model. Ext $=\{0,1\}$ measures whether turnover event $i$ is an external replacement or not. Forced $=\{0,1\}$ measure whether turnover event $i$ is a forced turnover. Proxy is one of $\left\{\right.$ Size, Error Mean $_{\text {, Erro }}$ Med, Dispersion, S\&P, Dist $\}$, and it measures the level of asymmetric information. Size is the market capitalization of the company. Error Mean and Error Med $_{\text {are }}$ mean and median analysts forecasting errors, respectively. Dispersion is the standard deviation of analysts forecasts. $S \& P$ indicates whether the announcing company is listed in the S\&P 500 Index. Dist is the shortest distance between the company's headquarters and the 21 most populous cities in U.S. \{InstOwnership, Anacov, BMratio, Spread and Turnover $\}$ are control variables that measure the characteristics of the company involved in turnover event $i$, where InstOwnership is the proportion of shares owned by institutional investors; Anacov $=\ln (1+$ AnalystFollowing $)$ measures firm analyst coverage; BMrario is the ratio of the company's book value to market capitalization; Spread is the high-low price measure for the bid-ask spread; Turnover = trading volume / total shares outstanding, which measures the stock turnover rate. ${ }^{*},{ }^{* *}$ and ${ }^{* * *}$ denote significance at the $10 \%, 5 \%$ and $1 \%$ level, respectively. Robust standard errors are in brackets. 
Table 10: Alternative proxies - Clean Environment

\begin{tabular}{|c|c|c|c|c|c|c|}
\hline \multirow[t]{2}{*}{ Dep. Variable } & \multicolumn{6}{|c|}{ CAR $[\mathrm{w}(-1), \mathrm{w}(+1)]$ : Market reaction in announcement period of week -1 to +1} \\
\hline & $(1)$ & $(2)$ & $(3)$ & (4) & $(5)$ & $(6)$ \\
\hline Proxy: & Size & Error $_{\text {Mean }}$ & Error $_{\text {Med }}$ & Dispersion & $S \& P$ & Dist \\
\hline Constant & $\begin{array}{l}0.0606^{*} \\
(0.0339)\end{array}$ & -0.0431 & $\begin{array}{l}-0.0429 \\
(0.0354)\end{array}$ & -0.0421 & $\begin{array}{l}-0.0206 \\
(0.0382)\end{array}$ & $\begin{array}{l}-0.0258 \\
(0.0362)\end{array}$ \\
\hline Ext & $\begin{array}{c}-0.0998^{*} \\
(0.0606)\end{array}$ & $\begin{array}{c}0.0134 \\
(0.0107)\end{array}$ & $\begin{array}{c}0.0140 \\
(0.0109)\end{array}$ & $\begin{array}{c}0.0091 \\
(0.0111)\end{array}$ & $\begin{array}{l}-0.0073 \\
(0.0109)\end{array}$ & $\begin{array}{c}0.0168 \\
(0.0128)\end{array}$ \\
\hline Forced & $\begin{array}{c}-0.2464^{* * *} \\
(0.0724)\end{array}$ & $\begin{array}{c}-0.0260^{* *} \\
(0.0128)\end{array}$ & $\begin{array}{c}-0.0265^{* *} \\
(0.0129)\end{array}$ & $\begin{array}{c}-0.0217^{*} \\
(0.0132)\end{array}$ & $\begin{array}{c}-0.0542^{* * *} \\
(0.0144)\end{array}$ & $\begin{array}{l}-0.0171 \\
(0.0149)\end{array}$ \\
\hline Proxy & $\begin{array}{l}-0.0071 \\
(0.0044)\end{array}$ & $\begin{array}{c}0.1129 \\
(0.1133)\end{array}$ & $\begin{array}{c}0.1321 \\
(0.1279)\end{array}$ & $\begin{array}{l}-0.0077 \\
(0.0170)\end{array}$ & $\begin{array}{c}-0.0336^{* * *} \\
(0.0119)\end{array}$ & $\begin{array}{c}0.0000 \\
(0.000169)\end{array}$ \\
\hline Ext $*$ Proxy & $\begin{array}{l}0.0144^{*} \\
(0.0082)\end{array}$ & $\begin{array}{c}-0.4040^{* * *} \\
(0.1053)\end{array}$ & $\begin{array}{c}-0.4455^{* *} \\
(0.1807)\end{array}$ & $\begin{array}{l}-0.0443 \\
(0.0287)\end{array}$ & $\begin{array}{l}0.0563^{*} \\
(0.0288)\end{array}$ & $\begin{array}{l}-0.0000446 \\
(0.0000306)\end{array}$ \\
\hline Forced $*$ Proxy & $\begin{array}{c}0.0288^{* * *} \\
(0.0094) \\
\end{array}$ & $\begin{array}{l}-0.1436 \\
(0.1122) \\
\end{array}$ & $\begin{array}{c}-0.1636 \\
(1271) \\
\end{array}$ & $\begin{array}{c}-0.0227 \\
(0.0170) \\
\end{array}$ & $\begin{array}{c}0.0797^{* * *} \\
(0.0266) \\
\end{array}$ & $\begin{array}{c}-0.0000631^{* *} \\
(0.000025) \\
\end{array}$ \\
\hline Controls & & & & & & \\
\hline InstOwnership & $\begin{array}{c}0.0031 \\
(0.0239)\end{array}$ & $\begin{array}{l}-0.0124 \\
(0.0241)\end{array}$ & $\begin{array}{l}-0.0122 \\
(0.2413)\end{array}$ & $\begin{array}{l}-0.0159 \\
(0.0252)\end{array}$ & $\begin{array}{c}0.0077 \\
(0.0232)\end{array}$ & $\begin{array}{c}0.0074 \\
(0.0241)\end{array}$ \\
\hline Size & & $\begin{array}{c}0.0064 \\
(0.0043)\end{array}$ & $\begin{array}{c}0.0064 \\
(0.0043)\end{array}$ & $\begin{array}{c}0.0050 \\
(0.0044)\end{array}$ & $\begin{array}{c}0.0044 \\
(0.0052)\end{array}$ & $\begin{array}{c}0.0038 \\
(0.0044)\end{array}$ \\
\hline Anacov & $\begin{array}{c}0.0031 \\
(0.0074)\end{array}$ & $\begin{array}{l}-0.0042 \\
(0.0077)\end{array}$ & $\begin{array}{l}-0.0044 \\
(0.0077)\end{array}$ & $\begin{array}{c}0.0023 \\
(0.0086)\end{array}$ & $\begin{array}{c}0.0024 \\
(0.0074)\end{array}$ & $\begin{array}{c}0.0008 \\
(0.0075)\end{array}$ \\
\hline BMratio & $\begin{array}{c}-0.0324^{* *} \\
(0.0141)\end{array}$ & $\begin{array}{c}-0.0089 \\
(0.0129)\end{array}$ & $\begin{array}{l}-0.0093 \\
(0.0130)\end{array}$ & $\begin{array}{c}-0.0152 \\
(0.0136)\end{array}$ & $\begin{array}{c}-0.0313^{* *} \\
(0.0136)\end{array}$ & $\begin{array}{c}-0.0302^{* *} \\
(0.0143)\end{array}$ \\
\hline Spread & $\begin{array}{c}0.3412 \\
(0.2833)\end{array}$ & $\begin{array}{c}0.7684^{* * *} \\
(0.2681)\end{array}$ & $\begin{array}{c}0.7570^{* * *} \\
(0.2674)\end{array}$ & $\begin{array}{c}0.6121^{* *} \\
(0.2986)\end{array}$ & $\begin{array}{c}0.3761 \\
(0.2845)\end{array}$ & $\begin{array}{c}0.4470 \\
(0.3099)\end{array}$ \\
\hline Turnover & $\begin{array}{c}0.0024 \\
(0.0066)\end{array}$ & $\begin{array}{c}0.0028 \\
(0.0069)\end{array}$ & $\begin{array}{c}0.0028 \\
(0.0069)\end{array}$ & $\begin{array}{c}0.0058 \\
(0.0075)\end{array}$ & $\begin{array}{c}0.0022 \\
(0.0065)\end{array}$ & $\begin{array}{c}0.0013 \\
(0.0070)\end{array}$ \\
\hline Observations & 484 & 476 & 476 & 455 & 484 & 475 \\
\hline R-Squared & 0.0998 & 0.0923 & 0.0867 & 0.0714 & 0.0942 & 0.0713 \\
\hline
\end{tabular}

Note: This table reports the results from the regression in which We use alternative proxies for information asymmetry in our baseline model in the clean environment. The model is as follows: $C A R_{i}[w(-1), w(+1)]=$ $\alpha+\beta_{e}$ Ext $_{i}+\beta_{f}$ Forced $_{i}+\beta_{p}$ Proxy $_{i}+\beta_{p e}$ Proxy $_{i} *$ Ext $_{i}+\beta_{p f}$ Proxy $_{i} *$ Forced $_{i}+\beta_{6}$ Control $_{i}+\epsilon_{i}$. The dependent variable is CAR from week -1 to week +1 , calculated based on the Fama-French three-factor model. Ext $=\{0,1\}$ measures whether turnover event $i$ is an external replacement or not. Forced $=\{0,1\}$ measures whether turnover event $i$ is a forced turnover. Proxy is one of $\left\{\right.$ Size, Error Mean $_{\text {, Erro }}$ Med, Dispersion, S\&P, Dist $\}$, and it measures the level of asymmetric information. Size is the market capitalization of the company. Error Mean $_{\text {and }}$ Error $_{M e d}$ are mean and median analysts forecasting errors, respectively. Dispersion is the standard deviation of analysts forecasts. $S \& P$ indicates whether the announcing company is listed in the S\&P 500 Index. Dist is the shortest distance between the company's headquarters and the 21 most populous cities in the U.S. \{InstOwnership, Anacov, BMratio, Spread and Turnover $\}$ are control variables that measure the characteristics of the company involved in turnover event $i$, where InstOwnership is the proportion of shares owned by institutional investors; Anacov $=\ln (1+$ AnalystFollowing $)$ measures firm analyst coverage; BMrario is the ratio of the company's book value to market capitalization; Spread is the high-low price measure for the bid-ask spread; Turnover = trading volume / total shares outstanding, which measures the stock turnover rate. ${ }^{*}, * *$ and $* * *$ denote significance at the $10 \%, 5 \%$ and $1 \%$ level, respectively. Robust standard errors are in brackets. 
TABle 11: The EfFect of ASymmetric information on FOrCEd/VOLUntary turnovers

\begin{tabular}{|c|c|c|c|c|c|c|c|}
\hline \multicolumn{8}{|c|}{ Panel A: Forced Turnovers (General Environment) } \\
\hline \multirow[t]{2}{*}{ Dep. Var } & \multicolumn{7}{|c|}{ CAR $[\mathrm{w}(-1), \mathrm{w}(+1)]:$ Market reaction in announcement period of week -1 to +1} \\
\hline & $(1)$ & $(2)$ & $(3)$ & $(4)$ & $(5)$ & $(6)$ & $(7)$ \\
\hline Proxy: & Anacov & Size & Error $_{\text {Mean }}$ & Error $_{M e d}$ & Dispersion & $S \& P$ & Dist \\
\hline \multirow[t]{2}{*}{ Constant } & $-0.1451^{* * *}$ & $-0.1985^{* * *}$ & -0.0198 & -0.0199 & -0.0096 & $-0.0395^{* * *}$ & -0.0081 \\
\hline & $(0.0552)$ & $(0.0554)$ & $(0.0122)$ & $(0.0122)$ & $(0.0111)$ & $(0.0138)$ & $(0.0145)$ \\
\hline \multirow[t]{2}{*}{ Proxy } & $0.0552^{* *}$ & $0.0231^{* * *}$ & $-0.0293^{* * *}$ & $-0.0292^{* * *}$ & $-0.0333^{* * *}$ & $0.0532^{*}$ & $-0.0000714^{* * *}$ \\
\hline & $(0.0230)$ & $(0.0068)$ & $(0.0058)$ & $(0.0049)$ & $(0.0100)$ & $(0.0276)$ & $(0.0000225)$ \\
\hline \multicolumn{8}{|c|}{ Panel B: Forced Turnovers (Clean Environment) } \\
\hline \multirow[t]{2}{*}{ Dep. Var } & \multicolumn{7}{|c|}{ CAR $[\mathrm{w}(-1), \mathrm{w}(+1)]:$ Market reaction in announcement period of week -1 to +1} \\
\hline & $(1)$ & $(2)$ & $(3)$ & $(4)$ & $(5)$ & $(6)$ & (7) \\
\hline Proxy: & Anacov & Size & Error $_{\text {Mean }}$ & Error $_{M e d}$ & Dispersion & $S \& P$ & Dist \\
\hline \multirow{2}{*}{ Constant } & $-0.1154^{* *}$ & $-0.2329 * * *$ & -0.0151 & -0.0153 & -0.0089 & $-0.0384^{* * *}$ & -0.0005 \\
\hline & $(0.0461)$ & $(0.0670)$ & $(0.0123)$ & $(0.0124)$ & $(0.0125)$ & $(0.0136)$ & $(0.0140)$ \\
\hline \multirow[t]{2}{*}{ Proxy } & $0.0453^{* *}$ & $0.0292 * * *$ & $-0.0294^{* * *}$ & $-0.0293^{* * *}$ & $-0.0338^{* * *}$ & $0.0812^{* * *}$ & $-0.0000779 * * *$ \\
\hline & $(0.0214)$ & $(0.0088)$ & $(0.0054)$ & $(0.0045)$ & $(0.0102)$ & $(0.0279)$ & $(0.0000190)$ \\
\hline \multicolumn{8}{|c|}{ Panel C: Voluntary Turnovers (General Environment) } \\
\hline \multirow[t]{2}{*}{ Dep. Var } & \multicolumn{7}{|c|}{ CAR $[\mathrm{w}(-1), \mathrm{w}(+1)]:$ Market reaction in announcement period of week -1 to +1} \\
\hline & $(1)$ & $(2)$ & (3) & $(4)$ & $(5)$ & $(6)$ & $(7)$ \\
\hline Proxy: & Anacov & Size & Error $_{\text {Mean }}$ & Error $_{M e d}$ & Dispersion & $S \& P$ & Dist \\
\hline \multirow[t]{2}{*}{ Constant } & -0.0009 & -0.0068 & $-0.0075^{* *}$ & $-0.0075^{* *}$ & $0.0104^{* * *}$ & $0.0102^{* *}$ & $0.0115^{* * *}$ \\
\hline & $(0.0132)$ & $(0.0234)$ & $(0.0037)$ & $(0.0122)$ & $(0.0040)$ & $(0.0052)$ & $(0.0042)$ \\
\hline \multirow[t]{2}{*}{ Proxy } & 0.0035 & 0.0000 & 0.0216 & 0.0194 & $-0.0287 * *$ & -0.0078 & $-0.0000220^{*}$ \\
\hline & $(0.0053)$ & $(0.0027)$ & $(0.0937)$ & $(0.0089)$ & $(0.0136)$ & $(0.0071)$ & $(0.0000121)$ \\
\hline \multicolumn{8}{|c|}{ Panel D: Voluntary Turnovers (Clean Environment) } \\
\hline \multirow[t]{2}{*}{ Dep. Var } & \multicolumn{7}{|c|}{ CAR $[\mathrm{w}(-1), \mathrm{w}(+1)]:$ Market reaction in announcement period of week -1 to +1} \\
\hline & $(1)$ & $(2)$ & $(3)$ & $(4)$ & $(5)$ & $(6)$ & $(7)$ \\
\hline Proxy: & Anacov & Size & Error $_{\text {Mean }}$ & Error $_{M e d}$ & Dispersion & $S \& P$ & Dist \\
\hline \multirow[t]{2}{*}{ Constant } & 0.0110 & -0.0243 & $0.0153^{* * *}$ & $0.0153^{* * *}$ & $0.0151^{* * *}$ & $0.0175^{* * *}$ & $0.0168^{* * *}$ \\
\hline & $(0.0153)$ & $(0.0295)$ & $(0.0043)$ & $(0.0043)$ & $(0.0045)$ & $(0.0053)$ & $(0.0050)$ \\
\hline \multirow[t]{2}{*}{ Proxy } & 0.0013 & -0.0014 & -0.0086 & -0.0087 & $-0.0204^{*}$ & -0.0116 & -0.0000165 \\
\hline & $(0.0065)$ & $(0.0036)$ & $(0.1162)$ & $(0.1076)$ & $(0.0124)$ & $(0.0088)$ & $(0.0000157)$ \\
\hline
\end{tabular}

Note: This table reports the effect of different proxies for the level of asymmetric information between a firm and its investors in sub-samples of only forced or only voluntary turnovers. Panels A and B report the results in sub-samples containing only forced turnovers. Panels $\mathrm{C}$ and $\mathrm{D}$ report the results in sub-samples containing only voluntary turnovers. Panels A and C report results for the general environment. Panels B and D report results for the clean environment. The dependent variable is the CAR over the event window spanning week -1 to week +1 , calculated based on the Fama-French three-factor model, representing market reaction in the turnover announcement period. $\left\{\right.$ Anacov, Size, Error Mean $_{\text {, Erro }}$ Med, Dispersion, S\&P, Dist $\}$ are proxies for the level of asymmetric information. Anacov $=\ln (1+$ AnalystFollowing $)$ is the analyst coverage for the company. Size is the market capitalization of the company. Error Mean $_{\text {and }}$ Error $_{M e d}$ are the mean and median analyst forecasting error, respectively. Dispersion is the standard deviation of the analyst forecasts. $S \& P$ indicates whether the announcing company is listed in the S\&P 500 Index. Dist is the shortest distance between the company's headquarters and the 21 most populous cities in the U.S. ${ }^{*}, * *$ and $* * *$ denote significance at the $10 \%, 5 \%$ and $1 \%$ level, respectively. Robust standard errors are in brackets. 
TABLE 12: EMBELLISHING FORCED INFORMATION

\begin{tabular}{c|ccc|ccc}
\hline \hline \multicolumn{2}{c}{ Panel A: Number of Embellishing Behavior } \\
\cline { 2 - 7 } Ananum & Forced & Embellishing & Fraction & Forced & Embellishing & Fraction \\
\hline 0 to 10 & 76 & 45 & $59.2 \%$ & 58 & 39 & $67.2 \%$ \\
10 to 20 & 35 & 14 & $40.0 \%$ & 17 & 7 & $41.2 \%$ \\
$>20$ & 14 & 5 & $35.7 \%$ & 8 & 3 & $37.5 \%$ \\
Total & 125 & 64 & $51.2 \%$ & 83 & 49 & $59.0 \%$ \\
\hline
\end{tabular}

\begin{tabular}{|c|c|c|c|c|c|c|}
\hline \multicolumn{7}{|c|}{ Panel B: Benefit from Embellishing Behavior } \\
\hline \multirow[t]{4}{*}{ Dep. Variable: } & \multicolumn{6}{|c|}{ CAR $[\mathrm{w}(-1), \mathrm{w}(+1)]$ : Market reaction in announcement period of week -1 to +1} \\
\hline & \multicolumn{3}{|c|}{ General Environment } & \multicolumn{3}{|c|}{ Clean Environment } \\
\hline & $(1)$ & $(2)$ & $(3)$ & $(4)$ & $(5)$ & $(6)$ \\
\hline & General & Ananum $<=10$ & Ananum $>10$ & General & Ananum $<=10$ & Ananum $>10$ \\
\hline \multirow[t]{2}{*}{ Constant } & -0.0705 & -0.0332 & -0.6018 & $-0.1912^{* *}$ & -0.1294 & -0.0814 \\
\hline & $(0.0729)$ & $(0.0877)$ & $(0.3702)$ & $(0.0847)$ & $(0.0924)$ & $(0.2014)$ \\
\hline \multirow[t]{2}{*}{ Hide } & $0.0548^{* * *}$ & $0.0648^{* *}$ & 0.0368 & 0.0313 & $0.0562^{*}$ & -0.0264 \\
\hline & $(0.0205)$ & $(0.0259)$ & $(0.0378)$ & $(0.0245)$ & $(0.0305)$ & $(0.0412)$ \\
\hline Controls & & & & & & \\
\hline \multirow[t]{2}{*}{ InstOwnership } & $-0.0935^{*}$ & $-0.1161^{*}$ & 0.0594 & -0.0751 & -0.0777 & -0.1787 \\
\hline & $(0.0506)$ & $(0.0631)$ & $(0.1529)$ & $(0.0553)$ & $(0.0671)$ & $(0.2696)$ \\
\hline \multirow[t]{2}{*}{ Size } & 0.0105 & 0.0115 & 0.0226 & $0.0281^{* * *}$ & $0.0281^{* *}$ & 0.0166 \\
\hline & $(0.0083)$ & $(0.0098)$ & $(0.0217)$ & $(0.0097)$ & $(0.0116)$ & $(0.0350)$ \\
\hline \multirow[t]{2}{*}{ Anacov } & $0.0344^{*}$ & 0.0290 & 0.1137 & 0.0233 & 0.0023 & 0.0202 \\
\hline & $(0.0192)$ & $(0.0305)$ & $(0.0833)$ & $(0.0209)$ & $(0.0306)$ & $(0.0350)$ \\
\hline \multirow[t]{2}{*}{ BMratio } & -0.0358 & -0.0336 & -0.0816 & $-0.0410^{*}$ & $-0.0544^{* *}$ & 0.0540 \\
\hline & $(0.0288)$ & $(0.0229)$ & $(0.0825)$ & $(0.0234)$ & $(0.0239)$ & $(0.0467)$ \\
\hline \multirow[t]{2}{*}{ Spread } & $-1.0732^{* *}$ & $-1.2612^{* * *}$ & 2.5960 & 0.7871 & 0.6043 & 2.3235 \\
\hline & $(0.4944)$ & $(0.3531)$ & $(1.5996)$ & $(0.7672)$ & $(0.6341)$ & $(3.0783)$ \\
\hline \multirow[t]{2}{*}{ Turnover } & -0.0013 & -0.0073 & -0.0065 & -0.0204 & $-0.0338^{*}$ & -0.0047 \\
\hline & $(0.0157)$ & $(0.1748)$ & $(0.0265)$ & $(0.0163)$ & $(0.0195)$ & $(0.0561)$ \\
\hline Observations & 125 & 76 & 49 & 83 & 58 & 25 \\
\hline R-Squared & 0.2933 & 0.4437 & 0.2351 & 0.2262 & 0.2873 & 0.2391 \\
\hline
\end{tabular}

Note: This table summarizes firm behavior that regarding embellishing details of forced turnovers. Panel A reports the fraction of firms that embellish the "forced" aspect by quantiles based on different levels of analyst coverage. Panel B reports the benefit from this embellishing behavior. The model used in panel B is as follows: $\mathrm{t}$ $C A R_{i}[w(-1), w(+1)]=\alpha+\beta_{1}$ Hide $+\beta_{2}$ Control $_{i}+\epsilon_{i}$. The dependent variable is CAR spanning week -1 to week +1 , calculated based on the Fama-French three-factor model, and it represents market reaction during the turnover announcement period. Ananum is the number of analysts following the company. Hide $=\{0,1\}$, indicates whether the company is embellishing or not. \{InstOwnership, Size, Anacov, BMratio, Spread and Turnover $\}$ are control variables, where InstOwnership is the proportion of shares owned by institutional investors; Size is the market capitalization of the company; Anacov $=\ln (1+$ AnalystFollowing $)$ measures firm analyst coverage; BMrario is the ratio of the company's book value to market capitalization; Spread is the high-low price measure for the bid-ask spread; Turnover $=$ trading volume / total shares outstanding, which measures the stock turnover rate. ${ }^{*}, * *$ and ${ }^{* * *}$ denote significance at the $10 \%, 5 \%$ and $1 \%$ level, respectively. Robust standard errors are in brackets. 
Table 13: Baseline Result (SIC-2 Industry Fixed Effect)

\begin{tabular}{|c|c|c|c|c|}
\hline \multirow{3}{*}{ Dep. Variable: } & \multicolumn{4}{|c|}{ CAR $[\mathrm{w}(-1), \mathrm{w}(+1)]:$ Market reaction in announcement period of week -1 to +1} \\
\hline & $(1)$ & $(2)$ & $(3)$ & $(4)$ \\
\hline & General Environment & Clean Environment & General Environment & Clean Environment \\
\hline \multirow[t]{2}{*}{ Constant } & 0.0339 & 0.0210 & 0.0157 & 0.0298 \\
\hline & $(0.0390)$ & $(0.0317)$ & $(0.0609)$ & $(0.0637)$ \\
\hline \multirow[t]{2}{*}{ Ext } & 0.00115 & -0.00914 & -0.00520 & -0.0106 \\
\hline & $(0.0270)$ & $(0.0308)$ & $(0.0285)$ & $(0.0339)$ \\
\hline \multirow[t]{2}{*}{ Forced } & $-0.139 * * *$ & $-0.136^{* * *}$ & $-0.141^{* * *}$ & $-0.136^{* * *}$ \\
\hline & $(0.0430)$ & $(0.0454)$ & $(0.0459)$ & $(0.0495)$ \\
\hline \multirow[t]{2}{*}{ Anacov } & -0.000629 & -0.00687 & -0.0139 & -0.0171 \\
\hline & $(0.00743)$ & $(0.00809)$ & $(0.00862)$ & $(0.0104)$ \\
\hline \multirow[t]{2}{*}{ Ext*Anacov } & 0.00684 & 0.00716 & 0.0118 & 0.00768 \\
\hline & $(0.0132)$ & $(0.0149)$ & $(0.0139)$ & $(0.0160)$ \\
\hline \multirow[t]{2}{*}{ Forced*Anacov } & $0.0496 * * *$ & $0.0482^{* *}$ & $0.0507^{* *}$ & $0.0517^{* *}$ \\
\hline & $(0.0185)$ & $(0.0209)$ & $(0.0197)$ & $(0.0225)$ \\
\hline \multicolumn{5}{|l|}{ Controls } \\
\hline \multirow[t]{2}{*}{ InstOwnership } & -0.00351 & 0.0112 & 0.00702 & 0.0127 \\
\hline & $(0.0236)$ & $(0.0239)$ & $(0.0285)$ & $(0.0290)$ \\
\hline \multirow[t]{2}{*}{ Size } & -0.00170 & 0.000667 & 0.000885 & 0.00254 \\
\hline & $(0.00443)$ & $(0.00388)$ & $(0.00443)$ & $(0.00458)$ \\
\hline \multirow{2}{*}{ BMratio } & $-0.0243^{* *}$ & $-0.0242^{*}$ & $-0.0304^{* *}$ & $-0.0298^{*}$ \\
\hline & $(0.0124)$ & $(0.0146)$ & $(0.0148)$ & $(0.0155)$ \\
\hline \multirow[t]{2}{*}{ Spread } & -0.244 & 0.0110 & -0.310 & -0.0221 \\
\hline & $(0.291)$ & $(0.300)$ & $(0.314)$ & $(0.255)$ \\
\hline \multirow[t]{2}{*}{ Turnover } & 0.00477 & 0.00289 & 0.00637 & 0.00168 \\
\hline & $(0.00700)$ & $(0.00676)$ & $(0.00794)$ & $(0.00741)$ \\
\hline Year FE & No & No & Yes & Yes \\
\hline Industry $\mathrm{FE}$ & No & No & Yes & Yes \\
\hline Observations & 750 & 484 & 750 & 484 \\
\hline R-Squared & 0.065 & 0.061 & 0.134 & 0.172 \\
\hline
\end{tabular}

Note: This table reports our baseline results. Columns 1 and 3 report the results in the general environment. Columns 2 and 4 report the results in the clean environment. Columns 1 and 2 do not control for fixed effects. Columns 3 and 4 control for year and industry fixed effects. Industries are classified based on the 2-digit SIC code. The model is as follows: $C A R_{i}[w(-1), w(+1)]=\alpha+\beta_{e}$ Ext $_{i}+\beta_{f}$ Forced $_{i}+\beta_{a}$ Anacov $_{i}+\beta_{a e}$ Anacov $_{i} *$ Ext $_{i}+\beta_{a f}$ Anacov $_{i} *$ Forced $_{i}+\beta_{6}$ InstOwnership $_{i}+\beta_{7}$ Size $_{i}+\beta_{8}$ BMratio $_{i}+\beta_{9}$ Spread $_{i}+\beta_{10}$ Turnover $_{i}+\epsilon_{i}$. The dependent variable is CAR spanning week -1 to week +1 , calculated based on the Fama-French three-factor model. Ext $=\{0,1\}$ measures whether a turnover event $i$ is an external replacement or not; Forced $=\{0,1\}$ measures whether turnover event $i$ is a forced turnover; Anacov $=\ln (1+$ AnalystFollowing $)$ measures analyst coverage for the company announcing turnover event $i$, as a proxy for the level of asymmetric information between the company and investors; \{InstOwnership, Size, BMratio, Spread and Turnover $\}$ are control variables that measure the characteristics of the company involved in turnover event $i$; InstOwnership is the proportion of shares owned by institutional investors; Size is the market capitalization of the company; BMrario is the ratio of the company's book value to market capitalization; Spread is the high-low price measure for the bid-ask spread; Turnover = trading volume / total shares outstanding, which measures the stock turnover rate. ${ }^{*}, * *$ and ${ }^{* * *}$ denote significance at the $10 \%, 5 \%$ and $1 \%$ level, respectively. Robust standard errors are in brackets. 
Table 14: Baseline Result (LARger Firms Subsample)

\begin{tabular}{|c|c|c|c|c|}
\hline \multirow[t]{3}{*}{ 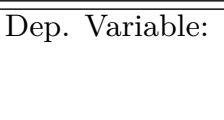 } & \multicolumn{4}{|c|}{ 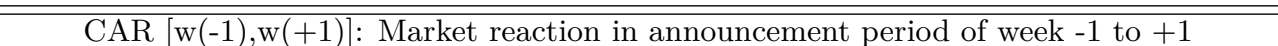 } \\
\hline & $(1)$ & $(2)$ & (3) & (4) \\
\hline & General Environment & Clean Environment & General Environment & Clean Environment \\
\hline \multirow[t]{2}{*}{ Constant } & 0.000991 & -0.0537 & 0.0340 & -0.0336 \\
\hline & $(0.0395)$ & $(0.0574)$ & $(0.0539)$ & $(0.0844)$ \\
\hline \multirow[t]{2}{*}{ Ext } & 0.0389 & 0.0404 & 0.0345 & -0.00648 \\
\hline & (0.0666) & $(0.0640)$ & $(0.0657)$ & $(0.0597)$ \\
\hline \multirow[t]{2}{*}{ Forced } & $-0.135^{* *}$ & $-0.189^{*}$ & $-0.130^{*}$ & $-0.199^{*}$ \\
\hline & $(0.0686)$ & $(0.0972)$ & $(0.0717)$ & $(0.104)$ \\
\hline \multirow[t]{2}{*}{ Anacov } & 0.00311 & -0.00418 & -0.00146 & -0.0109 \\
\hline & $(0.00906)$ & $(0.0105)$ & $(0.00970)$ & $(0.0122)$ \\
\hline \multirow[t]{2}{*}{ Ext*Anacov } & -0.000300 & -0.00571 & 0.000924 & 0.0114 \\
\hline & $(0.0266)$ & $(0.0255)$ & $(0.0260)$ & $(0.0240)$ \\
\hline \multirow[t]{2}{*}{ Forced*Anacov } & $0.0573^{* *}$ & $0.0707^{*}$ & $0.0555^{* *}$ & $0.0748^{*}$ \\
\hline & $(0.0263)$ & $(0.0396)$ & $(0.0276)$ & $(0.0430)$ \\
\hline \multicolumn{5}{|l|}{ Controls } \\
\hline \multirow[t]{2}{*}{ InstOwnership } & -0.0234 & -0.0540 & -0.0209 & -0.0541 \\
\hline & $(0.0267)$ & $(0.0342)$ & $(0.0288)$ & $(0.0394)$ \\
\hline \multirow[t]{2}{*}{ Size } & -0.00120 & 0.00589 & -0.000495 & 0.00773 \\
\hline & $(0.00420)$ & $(0.00622)$ & $(0.00460)$ & $(0.00711)$ \\
\hline \multirow[t]{2}{*}{ BMratio } & -0.00708 & 0.0117 & 0.00272 & 0.0175 \\
\hline & $(0.0176)$ & $(0.0269)$ & $(0.0192)$ & $(0.0312)$ \\
\hline \multirow[t]{2}{*}{ Spread } & $-0.896^{* * *}$ & -0.260 & $-0.922 * * *$ & -0.335 \\
\hline & $(0.262)$ & $(0.402)$ & $(0.272)$ & $(0.393)$ \\
\hline \multirow[t]{2}{*}{ Turnover } & $0.0201^{* *}$ & $0.0266^{* *}$ & $0.0201^{* *}$ & $0.0282^{* *}$ \\
\hline & $(0.00871)$ & $(0.0106)$ & $(0.00954)$ & $(0.0113)$ \\
\hline Year FE & No & No & Yes & Yes \\
\hline Industry FE & No & No & Yes & Yes \\
\hline Observations & 375 & 209 & 375 & 209 \\
\hline R-Squared & 0.199 & 0.108 & 0.218 & 0.181 \\
\hline
\end{tabular}

Note: This table reports our baseline results for the subsample consisting only large firms. Firms are classified as large firms if the size of the company is above the median. Columns 1 and 3 report the results in the general environment. Columns 2 and 4 report the results in the clean environment. Columns 1 and 2 do not control for fixed effects. Columns 3 and 4 control for year and industry fixed effects. Industries are classified based on the Fama-French 12 industry classification method. The model is as follows: $C A R_{i}[w(-1), w(+1)]=\alpha+\beta_{e} E_{2 x}+\beta_{f}$ Forced $_{i}+\beta_{a}$ Anacov $_{i}+$ $\beta_{a e}$ Anacov $_{i} *$ Ext $_{i}+\beta_{\text {af }}$ Anacov $_{i} *$ Forced $_{i}+\beta_{6}$ InstOwnership $_{i}+\beta_{7}$ Size $_{i}+\beta_{8}$ BMratio $_{i}+\beta_{9}$ Spread $_{i}+\beta_{10}$ Turnover $_{i}+\epsilon_{i}$. The dependent variable is CAR spanning week -1 to week +1 , calculated based on the Fama-French three-factor model. $E x t=\{0,1\}$ measures whether a turnover event $i$ is an external replacement or not; Forced $=\{0,1\}$ measures whether turnover event $i$ is a forced turnover; Anacov $=\ln (1+$ AnalystFollowing $)$ measures analyst coverage for the company announcing turnover event $i$, as a proxy for the level of asymmetric information between the company and investors; \{InstOwnership, Size, BMratio, Spread and Turnover\} are control variables that measure the characteristics of the company involved in turnover event $i$; InstOwnership is the proportion of shares owned by institutional investors; Size is the market capitalization of the company; BMrario is the ratio of the company's book value to market capitalization; Spread is the high-low price measure for the bid-ask spread; Turnover = trading volume / total shares outstanding, which measures the stock turnover rate. ${ }^{*},{ }^{* *}$ and ${ }^{* * *}$ denote significance at the $10 \%, 5 \%$ and $1 \%$ level, respectively. Robust standard errors are in brackets. 
Table 15: Baseline Result (COntrolling For governance measure)

\begin{tabular}{|c|c|c|c|c|c|c|}
\hline \multirow[t]{3}{*}{ Dep. Variable: } & \multicolumn{6}{|c|}{ CAR $[\mathrm{w}(-1), \mathrm{w}(+1)]:$ Market reaction in announcement period of week -1 to +1} \\
\hline & \multicolumn{3}{|c|}{ General Environment } & \multicolumn{3}{|c|}{ Clean Environment } \\
\hline & $(1)$ & $(2)$ & $(3)$ & $(4)$ & $(5)$ & $(6)$ \\
\hline Governance measure & E-index & WeakGov & ATI & E-index & WeakGov & ATI \\
\hline \multirow{2}{*}{ Constant } & 0.0563 & 0.0551 & 0.0625 & 0.0610 & 0.0651 & 0.0689 \\
\hline & $(0.0509)$ & $(0.0495)$ & $(0.0518)$ & $(0.0463)$ & $(0.0459)$ & $(0.0485)$ \\
\hline \multirow[t]{2}{*}{ Governance } & 0.00171 & 0.0121 & -0.000357 & 0.00278 & 0.00680 & -0.000320 \\
\hline & $(0.00283)$ & $(0.00821)$ & $(0.00420)$ & $(0.00283)$ & $(0.00892)$ & $(0.00478)$ \\
\hline \multirow[t]{2}{*}{ Ext } & -0.00206 & -0.00394 & -0.00181 & -0.00755 & -0.00782 & -0.00621 \\
\hline & $(0.0275)$ & $(0.0276)$ & $(0.0277)$ & $(0.0313)$ & $(0.0314)$ & $(0.0313)$ \\
\hline \multirow[t]{2}{*}{ Forced } & $-0.130 * * *$ & $-0.131 * * *$ & $-0.130 * * *$ & $-0.130 * * *$ & $-0.130 * * *$ & $-0.130^{* * *}$ \\
\hline & $(0.0427)$ & $(0.0428)$ & $(0.0428)$ & $(0.0458)$ & $(0.0459)$ & $(0.0463)$ \\
\hline \multirow[t]{2}{*}{ Anacov } & -0.00286 & -0.00307 & -0.00299 & -0.00898 & -0.00915 & -0.00933 \\
\hline & $(0.00803)$ & $(0.00801)$ & $(0.00805)$ & $(0.00836)$ & $(0.00833)$ & $(0.00841)$ \\
\hline \multirow[t]{2}{*}{ Ext*Anacov } & 0.00936 & 0.0103 & 0.00931 & 0.00691 & 0.00726 & 0.00652 \\
\hline & $(0.0135)$ & $(0.0135)$ & $(0.0135)$ & $(0.0150)$ & $(0.0150)$ & $(0.0150)$ \\
\hline \multirow{2}{*}{ Forced*Anacov } & $0.0462^{* *}$ & $0.0464^{* *}$ & $0.0464^{* *}$ & $0.0467 * *$ & $0.0467^{* *}$ & $0.0468^{* *}$ \\
\hline & $(0.0188)$ & $(0.0188)$ & $(0.0189)$ & $(0.0215)$ & $(0.0215)$ & $(0.0218)$ \\
\hline \multicolumn{7}{|l|}{ Controls } \\
\hline \multirow[t]{2}{*}{ InstOwnership } & -0.0122 & -0.0125 & -0.0120 & -0.00764 & -0.00799 & -0.00854 \\
\hline & $(0.0254)$ & $(0.0253)$ & $(0.0254)$ & $(0.0249)$ & $(0.0248)$ & $(0.0251)$ \\
\hline \multirow[t]{2}{*}{ Size } & -0.000907 & -0.000641 & -0.00117 & 0.00158 & 0.00157 & 0.00143 \\
\hline & $(0.00435)$ & $(0.00435)$ & $(0.00439)$ & $(0.00398)$ & $(0.00399)$ & $(0.00405)$ \\
\hline \multirow[t]{2}{*}{ BMratio } & -0.0216 & -0.0210 & -0.0221 & -0.0234 & -0.0234 & -0.0244 \\
\hline & $(0.0140)$ & $(0.0140)$ & $(0.0139)$ & $(0.0151)$ & $(0.0151)$ & $(0.0151)$ \\
\hline \multirow[t]{2}{*}{ Spread } & -0.349 & -0.341 & -0.351 & -0.175 & -0.172 & -0.174 \\
\hline & $(0.296)$ & $(0.296)$ & $(0.296)$ & $(0.261)$ & $(0.262)$ & $(0.263)$ \\
\hline \multirow[t]{2}{*}{ Turnover } & 0.00720 & 0.00701 & 0.00720 & 0.00481 & 0.00457 & 0.00486 \\
\hline & $(0.00751)$ & $(0.00751)$ & $(0.00749)$ & $(0.00684)$ & $(0.00680)$ & $(0.00684)$ \\
\hline Year FE & Yes & Yes & Yes & Yes & Yes & Yes \\
\hline Industry FE & Yes & Yes & Yes & Yes & Yes & Yes \\
\hline Observations & 727 & 727 & 727 & 469 & 469 & 469 \\
\hline R-Squared & 0.070 & 0.073 & 0.070 & 0.099 & 0.099 & 0.098 \\
\hline
\end{tabular}

Note: This table reports our baseline results while controlling the level of corporate governance. Columns 1 to 3 report the results in the general environment. Columns 4 to 6 report the results in the clean environment. The model is as follows: $C A R_{i}[w(-1), w(+1)]=\alpha+\beta_{g} G o v e r n a n c e_{i}+\beta_{e} E_{x} t_{i}+\beta_{f} F_{o r c e d}+$ $\beta_{a}$ Anacov $_{+} \beta_{a e}$ Anacov $_{i *}$ Ext $_{i}+\beta_{a f}$ Anacov $_{i} *$ Forced $_{i}+\beta_{6}$ InstOwnership $_{i}+\beta_{7}$ Size $_{i}+\beta_{8}$ BMratio $_{i}+\beta_{9}$ Spread $_{i}+\beta_{10}$ Turnover $_{i}+$ YearF E + IndustryFE $+\epsilon_{i}$ The dependent variable is CAR spanning week -1 to +1 , calculated based on the Fama-French 3 -factor model. Governance $i$ is one of $\left\{E-\right.$ index $_{i}$, WeakGov f $_{i}$ and $A T I_{i}$, measures the level of corporate governance. $E$ - index $i$ is the number of 6 managerial entrenchement provisions that firm $i$ has (Bebchuk, A., and Ferrell (2009)); WeakGov $i$ takes a value 1 if the firm's E-index is above the median (E-index $>3$ ), and 0 otherwise; $A T I_{i}$ is the number of 3 antitakeover provisions that firm i has (Cremers and Nair (2005)). Other explanatory variables' definitions are the same as those in the baseline model. Year and industry fixed effects are also controlled. Industries are classified based on the Fama-French 12 industry classification method. *, ** and *** denote significance at the $10 \%, 5 \%$ and $1 \%$ level, respectively. Robust standard errors are in brackets. 
Table 16: Baseline Result (Subsample Splits based on previous Performance)

\begin{tabular}{|c|c|c|c|c|c|c|c|c|}
\hline \multirow{3}{*}{$\begin{array}{l}\text { Dep. Variable: } \\
\text { Performance measure }\end{array}$} & \multicolumn{8}{|c|}{ CAR $[\mathrm{w}(-1), \mathrm{w}(+1)]:$ Market reaction in announcement period of week -1 to +1} \\
\hline & \multicolumn{2}{|c|}{ Monthly Stock Return } & \multicolumn{2}{|c|}{ Scaled Stock Return } & \multicolumn{2}{|c|}{ Monthly Stock Return } & \multicolumn{2}{|c|}{ Scaled Stock Return } \\
\hline & $(1)$ & $(2)$ & $(3)$ & $(4)$ & $(5)$ & $(6)$ & $(7)$ & $(8)$ \\
\hline over/under & Over & Under & Over & Under & Over & Under & Over & Under \\
\hline \multirow[t]{2}{*}{ Constant } & 0.0408 & 0.0413 & 0.0611 & 0.0178 & 0.0259 & 0.0817 & 0.0554 & 0.0541 \\
\hline & $(0.0366)$ & $(0.0581)$ & $(0.0388)$ & $(0.0535)$ & $(0.0451)$ & $(0.0799)$ & $(0.0599)$ & $(0.0683)$ \\
\hline \multirow[t]{2}{*}{ Ext } & -0.0159 & 0.00144 & -0.0307 & 0.0216 & -0.0101 & -0.000780 & -0.0206 & 0.0210 \\
\hline & $(0.0376)$ & $(0.0396)$ & $(0.0376)$ & $(0.0386)$ & $(0.0379)$ & $(0.0406)$ & $(0.0376)$ & $(0.0391)$ \\
\hline \multirow[t]{2}{*}{ Forced } & $-0.149^{* *}$ & $-0.145^{* * *}$ & $-0.169 * * *$ & $-0.143^{* *}$ & $-0.140^{* *}$ & $-0.141^{* *}$ & $-0.152^{* * *}$ & $-0.138^{* *}$ \\
\hline & $(0.0576)$ & $(0.0550)$ & $(0.0529)$ & $(0.0582)$ & $(0.0556)$ & $(0.0566)$ & $(0.0497)$ & $(0.0599)$ \\
\hline \multirow[t]{2}{*}{ Anacov } & $-0.0199^{*}$ & 0.00782 & $-0.0267^{* *}$ & 0.0109 & -0.0187 & 0.00181 & $-0.0288^{* *}$ & 0.00824 \\
\hline & $(0.0118)$ & $(0.00806)$ & $(0.0131)$ & $(0.00790)$ & $(0.0128)$ & $(0.00939)$ & $(0.0138)$ & $(0.00863)$ \\
\hline \multirow[t]{2}{*}{ Ext*Anacov } & 0.0110 & 0.00957 & 0.0158 & 0.00228 & 0.00745 & 0.0106 & 0.0111 & 0.00343 \\
\hline & $(0.0176)$ & $(0.0196)$ & $(0.0183)$ & $(0.0186)$ & $(0.0174)$ & $(0.0201)$ & $(0.0178)$ & $(0.0190)$ \\
\hline \multirow{2}{*}{ Forced*Anacov } & $0.0522^{* *}$ & $0.0520^{* *}$ & $0.0631^{* * *}$ & $0.0454^{*}$ & $0.0486^{* *}$ & $0.0511^{* *}$ & $0.0563^{* *}$ & $0.0426^{*}$ \\
\hline & $(0.0246)$ & $(0.0242)$ & $(0.0235)$ & $(0.0241)$ & $(0.0239)$ & $(0.0252)$ & $(0.0223)$ & $(0.0248)$ \\
\hline \multicolumn{9}{|l|}{ Controls } \\
\hline \multirow[t]{2}{*}{ InstOwnership } & 0.00663 & 0.00130 & 0.00861 & 0.00774 & 0.00124 & -0.00341 & 0.000518 & -0.000188 \\
\hline & $(0.0281)$ & $(0.0349)$ & $(0.0280)$ & $(0.0345)$ & $(0.0302)$ & $(0.0382)$ & $(0.0306)$ & $(0.0376)$ \\
\hline \multirow[t]{2}{*}{ Size } & 0.00207 & -0.00438 & 0.00391 & -0.00439 & 0.00307 & -0.00231 & 0.00683 & -0.00314 \\
\hline & $(0.00473)$ & $(0.00551)$ & $(0.00536)$ & $(0.00506)$ & $(0.00468)$ & $(0.00536)$ & $(0.00527)$ & $(0.00501)$ \\
\hline \multirow[t]{2}{*}{ BMratio } & $-0.0322^{*}$ & $-0.0276^{*}$ & $-0.0511^{* *}$ & -0.0118 & -0.0319 & -0.0245 & $-0.0570^{* *}$ & -0.00883 \\
\hline & $(0.0192)$ & $(0.0149)$ & $(0.0213)$ & $(0.0164)$ & $(0.0231)$ & $(0.0162)$ & $(0.0260)$ & $(0.0168)$ \\
\hline \multirow[t]{2}{*}{ Spread } & -0.112 & -0.356 & -0.0658 & -0.391 & -0.194 & -0.402 & -0.147 & -0.408 \\
\hline & $(0.302)$ & $(0.429)$ & $(0.311)$ & $(0.425)$ & $(0.289)$ & $(0.435)$ & $(0.290)$ & $(0.427)$ \\
\hline \multirow[t]{2}{*}{ Turnover } & 0.0122 & -0.00296 & 0.00893 & -0.000223 & 0.0130 & -0.00319 & 0.00903 & -0.00215 \\
\hline & $(0.00895)$ & $(0.0104)$ & $(0.00910)$ & $(0.00971)$ & $(0.00877)$ & $(0.0107)$ & $(0.00868)$ & $(0.00993)$ \\
\hline Year FE & No & No & No & No & Yes & Yes & Yes & Yes \\
\hline Industry FE & No & No & No & No & Yes & Yes & Yes & Yes \\
\hline Observations & 368 & 382 & 324 & 426 & 368 & 382 & 324 & 426 \\
\hline R-Squared & 0.061 & 0.109 & 0.088 & 0.103 & 0.107 & 0.134 & 0.151 & 0.134 \\
\hline
\end{tabular}

Note: This table reports our baseline results in sub-samples of firms that underperform or overperform the industry in the general environment. Firms are classified as underperformed (overperform) the industry if the last year performance is below (above) the industry median for that year. Industries are classified based on the Fama-French 12 industry classification method. Columns 1, 2, 5 and 6 use average monthly stock return to measure the firm performance. Columns $3,4,7$, and 8 use scaled monthly return (average monthly return scaled by the annual standard deviation) to measure the firm performance. Columns $1,3,5$ and 7 report the results for firms that overperform the industry. Columns 2, 4, 6 and 8 report the results for firms that underperform the industry. The model is as follows: $C A R_{i}[w(-1), w(+1)]=\alpha+\beta_{g}$ Governance $_{i}+\beta_{e}$ Ext $_{i}+\beta_{f}$ Forced $_{i}+\beta_{a}$ Anacov $+\beta_{a e}$ Anacov $_{i *}$ Ext $_{i}+\beta_{a f}$ Anacov $_{i} *$ Forced $_{i}+\beta_{6}$ InstOwnership $_{i}+$ $\beta_{7}$ Size $_{i}+\beta_{8}$ BMratio $_{i}+\beta_{9}$ Spread $_{i}+\beta_{10}$ Turnover $_{i}+$ YearFE $_{\text {IndustryFE }}+\epsilon_{i}$. The dependent variable is CAR spanning week -1 to +1 , calculated based on the Fama-French 3-factor model. All explanatory variables' definitions are the same as those in the baseline model. Year and industry fixed effects are also controlled. Industries are classified based on the Fama-French 12 industry classification method. ${ }^{*}, * *$ and $* * *$ denote significance at the $10 \%, 5 \%$ and $1 \%$ level, respectively. Robust standard errors are in brackets. 


\section{Appendix B: Online Materials for "CEO Turnover Announcements and Information Frictions" (Not for Publication)}

TABle B1: General information

\begin{tabular}{lcc}
\hline \hline & $(1)$ & $(2)$ \\
& General Environment & Clean Environment \\
\hline Total Observation & 750 & 484 \\
Forced & 125 & 83 \\
Voluntary & 625 & 401 \\
External & 167 & 132 \\
Internal & 583 & 352 \\
Forced \& External & 43 & 32 \\
Forced \& Internal & 82 & 51 \\
Voluntary \& External & 124 & 100 \\
Voluntary\& Internal & 501 & 301 \\
SP & 287 & 148 \\
MD & 207 & 142 \\
SM & 256 & 194 \\
\hline
\end{tabular}

Note: This table lists the sample sizes of each type of turnover 
TABle B2: Descriptive statistics

\begin{tabular}{|c|c|c|c|c|c|}
\hline \multicolumn{6}{|c|}{ Panel A: General Environment } \\
\hline & Mean & Standard deviation & Min & Max & Observation \\
\hline Analysts following & 10.98 & 7.7486 & 0 & 54 & 750 \\
\hline Anacov & 2.248 & $0 . .7403$ & 0 & 4.0073 & 750 \\
\hline Forecasting Error (Mean) & 0.0263 & 0.2889 & 0 & 7.7168 & 739 \\
\hline Forecasting Error (Median) & 0.0259 & 0.2807 & 0 & 7.5 & 739 \\
\hline Forecasting Dispersion & 0.1030 & 0.3366 & 0 & 7.3 & 707 \\
\hline Distance & 200.7417 & 312.4242 & 0.0191 & 3831.014 & 735 \\
\hline Inst Ownership & 0.7685 & 0.1946 & 0.0011 & 1.4916 & 750 \\
\hline Size (Market Cap) & 7.8986 & 1.5549 & 3.7047 & 12.8876 & 750 \\
\hline B/M Ratio & 0.5792 & 0.5097 & -1.6733 & 6.1643 & 750 \\
\hline \multicolumn{6}{|c|}{ Panel B: Clean Environment } \\
\hline & Mean & Standard deviation & Min & Man & Observation \\
\hline Analysts following & 9.83 & 7.0789 & 0 & 37 & 484 \\
\hline Anacov & 2.157 & 0.7160 & 0 & 3.6376 & 484 \\
\hline Forecasting Error (Mean) & 0.0349 & 0.3589 & 0 & 7.7168 & 476 \\
\hline Forecasting Error (Median) & 0.0341 & 0.3485 & 0 & 7.5 & 476 \\
\hline Forecasting Dispersion & 0.1102 & 0.4022 & 0 & 7.3 & 455 \\
\hline Distance & 198.3869 & 284.6728 & 0.0191 & 2067.698 & 475 \\
\hline Inst Ownership & 0.7715 & 0.1990 & 0.0065 & 1.4916 & 484 \\
\hline Size (Market Cap) & 7.5934 & 1.4018 & 3.7047 & 11.5845 & 484 \\
\hline B/M Ratio & 0.5836 & 0.5330 & -1.6007 & 6.1643 & 484 \\
\hline
\end{tabular}

Note: This table summarizes descriptive statistics for variables of interest. Panel A reports results in the general environment. Panel B reports results in the clean environment. 
Table B3: Baseline Result (robustness - Alternative Return model)

\begin{tabular}{|c|c|c|}
\hline \multirow[t]{3}{*}{ Dep. Variable: } & \multicolumn{2}{|c|}{ CAR $[\mathrm{w}(-1), \mathrm{w}(+1)]:$ Market reaction in week -1 to +1} \\
\hline & $(1)$ & $(2)$ \\
\hline & General Environment & Clean Environment \\
\hline \multirow[t]{2}{*}{ Constant } & 0.0314 & 0.0162 \\
\hline & $(0.0433)$ & $(0.0324)$ \\
\hline \multirow[t]{2}{*}{ Ext } & -0.0165 & -0.0221 \\
\hline & $(0.0278)$ & $(0.0331)$ \\
\hline \multirow[t]{2}{*}{ Forced } & $-0.1370^{* * *}$ & $-0.1268 * * *$ \\
\hline & $(0.0481)$ & $(0.0461)$ \\
\hline \multirow[t]{2}{*}{ Anacov } & 0.0012 & -0.0074 \\
\hline & $(0.0074)$ & $(0.0085)$ \\
\hline \multirow{2}{*}{ Ext $*$ Anacov } & 0.0147 & 0.0125 \\
\hline & $(0.0135)$ & $(0.0158)$ \\
\hline \multirow{2}{*}{ Forced $*$ Anacov } & $0.0463^{* *}$ & $0.0435^{* *}$ \\
\hline & $(0.0201)$ & $(0.0212)$ \\
\hline \multicolumn{3}{|l|}{ Controls } \\
\hline \multirow[t]{2}{*}{ InstOwnership } & 0.0070 & 0.0071 \\
\hline & $(0.0248)$ & $(0.0251)$ \\
\hline \multirow[t]{2}{*}{ Size } & -0.0015 & 0.0019 \\
\hline & $(0.0047)$ & $(0.0042)$ \\
\hline \multirow[t]{2}{*}{ BMratio } & $-0.0288^{* *}$ & $-0.0401^{* * *}$ \\
\hline & $(0.0135)$ & $(0.0134)$ \\
\hline \multirow[t]{2}{*}{ Spread } & -0.1988 & 0.3453 \\
\hline & $(0.4669)$ & $(0.2895)$ \\
\hline \multirow[t]{2}{*}{ Turnover } & -0.0001 & 0.0019 \\
\hline & $(0.0071)$ & $(0.0072)$ \\
\hline Observations & 750 & 484 \\
\hline R-Squared & 0.0649 & 0.0771 \\
\hline
\end{tabular}

Note: This table reports our baseline results. The model is as follows: $C A R_{i}[w(-1), w(+1)]=\alpha+\beta_{e} E_{i} t_{i}+\beta_{f} F_{o r c e d}+$ $\beta_{a}$ Anacov $_{i}+\beta_{a e}$ Anacov $_{i} *$ Ext $_{i}+\beta_{a f}$ Anacov $_{i} *$ Forced $_{i}+\beta_{6}$ InstOwnership $_{i}+\beta_{7}$ Size $_{i}+\beta_{8}$ BMratio $_{i}+\beta_{9}$ Spread $_{i}+$ $\beta_{10}$ Turnover ${ }_{i}+\epsilon_{i}$. The dependent variable is CAR spanning week -1 to week +1 , calculated based on the Carhart four-factor model. $E x t=\{0,1\}$ measures whether turnover event $i$ is an external replacement or not; Forced $=\{0,1\}$ measures whether turnover event $i$ is a forced turnover; Anacov $=\ln (1+$ AnalystFollowing $)$ measures analyst coverage for the company announcing turnover event $i$, as a proxy for the level of asymmetric information between the company and investors; $\{$ InstOwnership, Size, BMratio, Spread and Turnover $\}$ are control variables that measure the characteristics of the company involved in turnover event $i$; InstOwnership is the proportion of shares owned by institutional investors; Size is the market capitalization of the company; BMrario is the ratio of the company's book value to market capitalization; Spread is the high-low price measure for the bid-ask spread; Turnover $=$ trading volume / total shares outstanding, measures the stock turnover rate. ${ }^{*},{ }^{* *}$ and ${ }^{* * *}$ denote significance at the $10 \%, 5 \%$ and $1 \%$ level, respectively. Robust standard errors are in brackets. 


\section{TABle B4: EFFECT OF ASYMMETRIC INFORMATION IN FORCED/VOLUNTARY TURNOVERS}

(ROBUSTNESS - ALTERNATIVE RETURN MODEL)

\begin{tabular}{|c|c|c|c|c|c|c|c|}
\hline \multicolumn{8}{|c|}{ Panel A: Forced Turnovers (General Environment) } \\
\hline \multirow[t]{2}{*}{ Dep. Var } & \multicolumn{7}{|c|}{ CAR $[\mathrm{w}(-1), \mathrm{w}(+1)]$ : Market reaction in announcement period of week -1 to +1} \\
\hline & $(1)$ & $(2)$ & $(3)$ & $(4)$ & $(5)$ & (6) & (7) \\
\hline Proxy: & Anacov & Size & Error $_{\text {Mean }}$ & Error $_{M e d}$ & Dispersion & $S \& P$ & Dist \\
\hline \multirow[t]{2}{*}{ Constant } & $-0.1443^{* *}$ & $-0.2055^{* * *}$ & $-0.0222^{*}$ & $-0.0223^{*}$ & -0.0115 & $-0.0420^{* * *}$ & -0.009055 \\
\hline & $(0.0552)$ & $(0.0579)$ & $(0.0125)$ & $(0.0126)$ & $(0.0113)$ & $(0.0141)$ & $(0.0149855)$ \\
\hline \multirow[t]{2}{*}{ Proxy } & $0.0537^{* *}$ & $0.0237^{* * *}$ & $-0.0299 * * *$ & $-0.0296^{* * *}$ & $-0.0355^{* * *}$ & $0.0536^{*}$ & $-0.0000773^{* * *}$ \\
\hline & $(0.0236)$ & $(0.0072)$ & $(0.0065)$ & $(0.0053)$ & $(0.0127)$ & $(0.0284)$ & $(0.0000223)$ \\
\hline \multicolumn{8}{|c|}{ Panel B: Forced Turnovers (Clean Environment) } \\
\hline \multirow[t]{2}{*}{ Dep. Var } & \multicolumn{7}{|c|}{ CAR $[\mathrm{w}(-1), \mathrm{w}(+1)]:$ Market reaction in announcement period of week -1 to +1} \\
\hline & $(1)$ & $(2)$ & $(3)$ & $(4)$ & $(5)$ & $(6)$ & $(7)$ \\
\hline Proxy: & Anacov & Size & Error $_{\text {Mean }}$ & Error $_{\text {Med }}$ & Dispersion & $S \& P$ & Dist \\
\hline \multirow[t]{2}{*}{ Constant } & $-0.1087^{* *}$ & $-0.2436^{* * *}$ & -0.0171 & -0.0173 & -0.0106 & $-0.0413^{* * *}$ & -0.0007524 \\
\hline & $(0.0465)$ & $(0.0695)$ & $(0.0126)$ & $(0.0126)$ & $(0.0126)$ & $(0.0138)$ & $(0.0142481)$ \\
\hline \multirow[t]{2}{*}{ Proxy } & $0.0412^{* *}$ & $0.0303^{* * *}$ & $-0.0300^{* * *}$ & $-0.0297^{* * *}$ & $-0.0361^{* * *}$ & $0.0848^{* * *}$ & $-0.0000864^{* * *}$ \\
\hline & $(0.0217)$ & $(0.0092)$ & $(0.0060)$ & $(0.0048)$ & $(0.0128)$ & $(0.0288)$ & $(0.0000185)$ \\
\hline \multicolumn{8}{|c|}{ Panel C: Voluntary Turnovers (General Environment) } \\
\hline \multirow[t]{2}{*}{ Dep. Var } & \multicolumn{7}{|c|}{ CAR $[\mathrm{w}(-1), \mathrm{w}(+1)]:$ Market reaction in announcement period of week -1 to +1} \\
\hline & $(1)$ & $(2)$ & $(3)$ & $(4)$ & $(5)$ & $(6)$ & (7) \\
\hline Proxy: & Anacov & Size & Error $_{\text {Mean }}$ & Error $_{M e d}$ & Dispersion & $S \& P$ & Dist \\
\hline \multirow[t]{2}{*}{ Constant } & -0.0078 & 0.0001 & $0.0084^{* *}$ & $0.0084^{* *}$ & $0.0106^{* *}$ & $0.0098^{*}$ & $0.0126^{* * *}$ \\
\hline & $(0.0136)$ & $(0.0245)$ & $(0.0039)$ & $(0.0039)$ & $(0.0041)$ & $(0.0054)$ & $(0.0044)$ \\
\hline \multirow[t]{2}{*}{ Proxy } & 0.0069 & 0.0010 & 0.0051 & 0.0054 & -0.0199 & -0.0052 & $-0.0000254^{* *}$ \\
\hline & $(0.0054)$ & $(0.0028)$ & $(0.1270)$ & $(0.1194)$ & $(0.0147)$ & $(0.0074)$ & $(0.0000126)$ \\
\hline \multicolumn{8}{|c|}{ Panel D: Voluntary Turnovers (Clean Environment) } \\
\hline \multirow[t]{2}{*}{ Dep. Var } & \multicolumn{7}{|c|}{ CAR $[\mathrm{w}(-1), \mathrm{w}(+1)]:$ Market reaction in announcement period of week -1 to +1} \\
\hline & $(1)$ & $(2)$ & $(3)$ & $(4)$ & $(5)$ & $(6)$ & $(7)$ \\
\hline Proxy: & Anacov & Size & Error Mean $_{\text {M }}$ & Error $_{M e d}$ & Dispersion & $S \& P$ & Dist \\
\hline \multirow[t]{2}{*}{ Constant } & 0.0070 & 0.0204 & $0.0158^{* * *}$ & $0.0158^{* * *}$ & $0.0150^{* * *}$ & $0.0176^{* * *}$ & $0.0174^{* * *}$ \\
\hline & $(0.0157)$ & $(0.0316)$ & $(0.0045)$ & $(0.0045)$ & $(0.0048)$ & $(0.0055)$ & $(0.0052)$ \\
\hline \multirow[t]{2}{*}{ Proxy } & 0.0031 & -0.0009 & -0.0478 & -0.0427 & -0.0169 & -0.0121 & -0.0000209 \\
\hline & $(0.0066)$ & $(0.0039)$ & $(0.1625)$ & $(0.1494)$ & $(0.0154)$ & $(0.0090)$ & $(0.0000164)$ \\
\hline
\end{tabular}

Note: This table reports the effect of different proxies for the level of asymmetric information between a firm and its investors in sub-samples of only forced or only voluntary turnovers. Panels A and B report the results in sub-samples containing only forced turnovers. Panels $\mathrm{C}$ and D report the results in sub-samples containing only voluntary turnovers. Panels A and C report results for the general environment. Panels B and D report results for the clean environment. The dependent variable is the CAR over the event window spanning week -1 to week +1 , calculated based on the Carhart four-factor model, representing market reaction in the turnover announcement period. \{Anacov, Size, Error Mean $_{\text {, Erro }}$ Med, Dispersion, S\&P, Dist $\}$ are proxies for the level of asymmetric information. Anacov $=\ln (1+$ AnalystFollowing $)$ is the analyst coverage for the company. Size is the market capitalization of the company. Error Mean $_{\text {and }}$ Error $_{M e d}$ are mean and median analyst forecasting errors, respectively. Dispersion is the standard deviation of the analyst forecasts. $S \& P$ indicates whether the announcing company is listed in the $\mathrm{S} \& \mathrm{P} 500$ Index. Dist is the shortest distance between the company's headquarters and the 21 most populous cities in the US. $*$, ** and ${ }^{* * *}$ denote significance at the $10 \%, 5 \%$ and $1 \%$ level, respectively. Robust standard errors are in brackets. 
TABLE B5: EMBELLISHING FORCED INFORMATION

\begin{tabular}{|c|c|c|c|c|c|c|}
\hline \multirow[t]{4}{*}{ Dep. Variable: } & \multicolumn{6}{|c|}{ CAR $[\mathrm{w}(-1), \mathrm{w}(+1)]$ : Market reaction in announcement period of week -1 to +1} \\
\hline & \multicolumn{3}{|c|}{ General Environment } & \multicolumn{3}{|c|}{ Clean Environment } \\
\hline & (1) & $(2)$ & $(3)$ & $(4)$ & $(5)$ & $(6)$ \\
\hline & General & Ananum $<=10$ & Ananum $>10$ & General & Ananum $<=10$ & Ananum $>10$ \\
\hline \multirow[t]{2}{*}{ Constant } & -0.0687 & -0.0301 & $-0.6600^{*}$ & $-0.1818^{* *}$ & -0.1056 & -0.1705 \\
\hline & $(0.0694)$ & $(0.0837)$ & $(0.3873)$ & $(0.0857)$ & $(0.0927)$ & $(0.2085)$ \\
\hline \multirow[t]{2}{*}{ Hide } & $0.0544^{* * *}$ & $0.0719^{* * *}$ & 0.0283 & 0.0320 & $0.0670 * *$ & -0.0395 \\
\hline & $(0.0208)$ & $(0.0266)$ & $(0.0397)$ & $(0.0253)$ & $(0.0305)$ & $(0.0421)$ \\
\hline \multirow{3}{*}{ InstOwnership } & & & & & & \\
\hline & $-0.0908^{*}$ & $-0.1159^{*}$ & 0.0709 & -0.0756 & -0.0793 & -0.1783 \\
\hline & $(0.0499)$ & $(0.0627)$ & $(0.1636)$ & $(0.0584)$ & $(0.0710)$ & $(0.2706)$ \\
\hline \multirow[t]{2}{*}{ Size } & 0.0122 & 0.0108 & 0.0261 & $0.0303^{* * *}$ & $0.0261^{* *}$ & 0.0221 \\
\hline & $(0.0085)$ & $(0.0101)$ & $(0.0233)$ & $(0.0102)$ & $(0.0118)$ & $(0.0338)$ \\
\hline \multirow[t]{2}{*}{ Anacov } & 0.0278 & 0.0251 & 0.1233 & 0.0139 & -0.0071 & 0.0377 \\
\hline & $(0.0194)$ & $(0.0305)$ & $(0.0872)$ & $(0.0215)$ & $(0.0312)$ & $(0.1647)$ \\
\hline \multirow[t]{2}{*}{ BMratio } & -0.0376 & -0.0324 & -0.0885 & -0.0369 & $-0.0465^{*}$ & 0.0009 \\
\hline & $(0.0301)$ & $(0.0245)$ & $(0.0858)$ & $(0.0234)$ & $(0.0250)$ & $(0.0435)$ \\
\hline \multirow[t]{2}{*}{ Spread } & $-1.2340^{* * *}$ & $-1.4061^{* * *}$ & 1.8760 & 0.3798 & 0.1611 & 1.2305 \\
\hline & $(0.4509)$ & $(0.3105)$ & $(1.6859)$ & $(0.8205)$ & $(0.6917)$ & $(3.1255)$ \\
\hline \multirow[t]{2}{*}{ Turnover } & 0.0001 & -0.0032 & -0.0011 & -0.0185 & -0.0286 & 0.0063 \\
\hline & $(0.0157)$ & $(0.0173)$ & $(0.0274)$ & $(0.0166)$ & $(0.0198)$ & $(0.0528)$ \\
\hline Observations & 125 & 76 & 49 & 83 & 58 & 25 \\
\hline R-Squared & 0.3084 & 0.4682 & 0.2286 & 0.2258 & 0.2913 & 0.2523 \\
\hline
\end{tabular}

Note: This table summarizes firm behavior that regarding embellishing details of forced turnovers. Panel A reports the fraction of firms that embellish the "forced" aspect by quantiles based on different levels of analyst coverage. Panel B reports the benefit from this embellishing behavior. The model used in panel B is as follows: $C A R_{i}[w(-1), w(+1)]=\alpha+\beta_{1}$ Hide $+\beta_{2}$ Control $_{i}+\epsilon_{i}$. The dependent variable is CAR spanning week -1 to week +1, calculated based on the Carhart four-factor model, and it represents market reaction during the turnover announcement period. Ananum is the number of analysts following the company. Hide $=\{0,1\}$, indicates whether the company is embellishing or not. \{InstOwnership, Size, Anacov, BMratio, Spread and Turnover $\}$ are control variables, where InstOwnership is the proportion of shares owned by institutional investors; Size is the market capitalization of the company; Anacov $=\ln (1+$ AnalystFollowing $)$ measures firm analyst coverage; BMrario is the ratio of the company's book value to market capitalization; Spread is the high-low price measure for the bid-ask spread; Turnover $=$ trading volume / total shares outstanding, which measures the stock turnover rate. * ${ }^{* *}$ and $* * *$ denote significance at the $10 \%, 5 \%$ and $1 \%$ level, respectively. Robust standard errors are in brackets. 